\title{
NIETZSCHE COMO DESTINO DA FILOSOFIA E DA HUMANIDADE? INTERPRETAÇÃO CONTEXTUAL DO § 1 DO CAPÍTULO "POR QUE SOU UM DESTINO", DE ECCE HOMO'1
}

\author{
Werner Stegmaier ${ }^{2}$
}

Tradução: João Paulo Simões Vilas Bôas ${ }^{3}$

RESUMO: A tradução que se segue é uma versão resumida e revisada do artigo "Schicksal NietzSche? $\mathrm{Zu}$ Nietzsches Selbsteinschätzung als Schicksal der Philosophie und der Menschheit (Ecce Homo, Warum ich ein Schicksal bin \$1)" - publicado originalmente em Nietzsche-Studien 37 (2008) — que foi especialmente preparada para ser apresentada em palestra organizada pelo Grupo de Pesquisa Spinoza \& Nietzsche (SpiN), na Universidade Federal do Rio de Janeiro, em 14/09/2009. No texto, o autor faz uso de sua própria metodologia filológico-hermenêutica, denominada interpretação contextual, com vistas a esclarecer os conceitos do primeiro aforismo de "por que sou um destino", de Ecce Homo no seu contexto próprio, no contexto de EcCe Homo e no contexto da obra de Nietzsche como um todo.

PALAVRAS-CHAVE: ECCe Homo. Interpretação contextual. Destino. Loucura. Verdade.

\footnotetext{
${ }^{1}$ Versão resumida e revisada do artigo "Schicksal Nietzsche? Zu Nietzsches Selbsteinschätzung als Schicksal der Philosophie und der Menschheit (Ecce Homo, Warum ich ein Schicksal bin §1)", in: Nietzsche-Studien 37. Berlin/New York: Walter de Gruyter, 2008, p. 62-114. (Nota do tradutor: O presente texto foi apresentado em palestra organizada pelo Grupo de Pesquisa Spinoza \& Nietzsche - SpiN, na Universidade Federal do Rio de Janeiro (UFRJ), em 14/09/2009).

${ }^{2}$ Professor Doutor na Ernst Moritz Arndt Universität Greifswald e coeditor dos Nietzsche-Studien.

${ }^{3}$ Nota do tradutor: Exceto quando houver menção em contrário, todas as citações das obras de Nietzsche foram extraídas das traduções de Paulo C. de Souza, publicadas pela Editora Companhia das Letras: Humano, demasiado humano (2004), Aurora (2004), A Gaia Ciência (2004), Além do Bem e do Mal (2004), Genealogia da Moral (2004), Crepúsculo dos Ídolos (2006), Ecce Homo (2004) e O Anticristo (2007). As citações de Assim falou Zaratustra foram extraídas da tradução de Mário da Silva, publicada pela Editora Civilização Brasileira (2006). Gostaria de manifestar profundo agradecimento a Dirk Sölter, pelo trabalho de revisão e pelas importantes observações e esclarecimentos que em muito contribuíram para a melhoria da tradução.
} 


\section{Estrutura}

\section{A presunção nietzscheana de uma fatídica transvaloração de todos os}

valores

\section{2 §1 do capítulo "Por que sou um destino", de Ecce Homo}

\section{A decidibilidade da verdade como destino da humanidade}

1 A presunção nietzscheana de uma fatídica transvaloração de todos os valores

As pretensões nietzscheanas à filosofia, já presunçosas em sua juventude, atingem o extremo ao final de EcCe Homo. "Eu carrego nos ombros", escreve o pensador, "o destino da humanidade" (ECCe Homo, O Caso Wagner, §4). Em "Por que sou um destino", ele vai tão longe, a ponto de nomear a si próprio como um destino. Nenhum filósofo antes de Nietzsche se expressou assim: ninguém se declarou como um destino, não apenas da filosofia, mas também da própria humanidade. Contudo, quem se ocupa com Nietzsche precisa estar pronto para lidar com essa sua pretensão inaudita ${ }^{4}$.

${ }^{4}$ Martin Heidegger, sobretudo, defendeu essa opinião em Nietzsche, vol 1. Ed. Pfullingen, 1961. p. 473s. (Nota do tradutor: Em língua portuguesa, HEIDEGGER, M. Nietzsche, vol 1. Trad. Marco Antonio Casanova. Rio de Janeiro: Forense Universitária, 2007, p. 369). Em Ecce Homo, não se trata do "ápice de uma delirante apologia de si e de um narcisismo desmedido", nem de um "prenúncio da loucura prestes a irromper", tampouco de uma "biografia", mas, de fato, de "um destino". Não de um acontecimento particular, porém, antes, da história da modernidade entendida como o fim dos tempos do ocidente. Apesar de todas as críticas à interpretação heideggeriana de Nietzsche, pode-se seguir adiante com essa opinião. (Cf. do próprio autor [Heideggers] Auseinandersetzung mit Nietzsche I Metaphysische Interpretation eines Anti-Metaphysikers, in: Heidegger-Handbuch. Leben - Werk Wirkung, hg. von Dieter Thomä, Stuttgart/Weimar, 2003, p. 202-210). No texto Autobiography as Gestalt: Nietzsche's Ecce Homo (1981), in: O'HARA, Daniel (Ed.). Why Nietzsche now? Bloomington, 1985, p. 271-290, Rodolphe Gasché concorda com Heidegger, ao interpretar Ecce Homo como uma "forma" no sentido da forma de um ente ( $1 \delta \varepsilon \alpha$, no sentido de Platão, $\varepsilon 1 \delta o \zeta$ no sentido de Aristóteles), mas que agora é a forma assumida pela vida de Nietzsche. Contrariamente a Heidegger, no entanto, Gasché entende que essa forma se exaure no pensamento do eterno retorno, por meio da "dualidade metafísica do ser e do devir" (p.275). Mesmo um intérprete tão vigoroso como Eric Blondel, no texto Nietzsches Selbstsucht in ECCe Homo, in: Perspektiven der Philosophie 20 (1994), p. 291-300, pôde ver em ECCe Homo apenas "um amontoado de mentiras, falsificações e encobrimentos, em uma palavra: egoísmo" (p. 293) - por meio do qual Nietzsche expressamente reconhece a si próprio (EH, Porque sou tão inteligente, §9). Em Über die Verbesserung der guten Nachricht. Nietzsches fünftes "Evangelium" Discurso proferido em 25 de agosto de 2000, em Weimar, por ocasião dos 100 anos de morte de Friedrich Nietzsche, Frankfurt am Main, 2001, Peter Sloterdijk atesta o "egoísmo" (p. 45) ou a "megalomania" (p. 40) de Nietzsche, ambos colocados aqui entre aspas: "as luzes das auto-afirmações de Nietzsche são tão excessivas, que mesmo o leitor mais benevolente, mais espírito-livre e até mesmo aquele com o entendimento mais entorpecido desvia o olhar" (p. 40); mas ele as legitima na medida em que descreve "o evento Nietzsche como uma catástrofe na história da fala" (p. 8), "a abundância obscena de auto-elogios" como desencadeamento da "força elogiosa da fala" ou do "bem dizer" — um bem dizer, não para superar a vontade do próprio Nietzsche, mas sim ao "sistema de mal-dizer" da metafísica e da moral (p. 28s). Com o "cinismo de um Diógenes de Sínope", Nietzsche esforçou-se por realizar a 
Diante disso, precisamos então nos perguntar: por que ele se expressou desse modo? Teríamos aqui apenas uma retórica excessiva ou a transvaloração nietzscheana poderia de fato ser um destino? A resposta não é fácil, Nietzsche não a oferece facilmente. A presunção poderia apenas ser um recurso retórico e também ser objetivamente fundamentada: o filósofo poderia ter se expressado dessa maneira inconveniente apenas para ser ouvido - tornando-se igualmente conhecido e reconhecido por suas pretensões desmedidas. Mas essa pretensão poderia também ser irônica.

A ironia já fora empregada antes por Sócrates, na forma de seu saber paradoxal de nada saber. Assim como ele se apresentava diante de seus interlocutores como alguém que sabia mais, eles e, mais tarde, os leitores dos diálogos nos quais Platão o apresentou, acabavam por ter de considerar o seu nada-saber como algo apenas alegado, apenas arrogado. Contudo, essa ironia era coisa séria: não se podia naquela época, nem se pode tampouco hoje, saber exatamente quando Sócrates estava sendo irônico e quando não o estava, separando o que ele falava apenas como gracejo e o que falava seriamente; pois falar ironicamente quer dizer justamente isso: não permitir que se saiba quando e se estamos falando ironicamente. Somente sob a proteção dessa pressuposição, dessa presunção, é que o Sócrates dos diálogos platônicos podia então interrogar seus interlocutores do jeito como o fazia e revelar o saber deles como sem fundamento.

Sócrates também tratou com ironia o próprio oráculo de Delfos que preconizava os destinos e que proclamara que ninguém era tão sábio quanto ele - , pois não aceitou sua revelação como pertencente a um oráculo divino, mas antes pôs-se persistentemente a prová-la, para o que ele perguntava a outros, se eles não seriam mais sábios que ele próprio. Sócrates arrogou-se submeter um oráculo divino a uma prova filosófica e, para tanto, reportou-se a um deus próprio, seu daimónion, que falava somente com ele e permanecia desconhecido aos demais. Com essa dupla presunção, a qual, por fim, custou-lhe a vida ${ }^{5}$, ele tornou-se um destino da filosofia e da humanidade. Assim como Nietzsche, Sócrates obteve, com "ironia históricouniversal" (Ecce Homo, O Caso Wagner, §4), uma importância históricouniversal.

"transvaloração de todo o desagradável e penoso" (p. 46) e com a "virtude dadivosa" da qual fala seu Zaratustra, ofereceu a seus leitores uma nova inocência de um bem-dizer abundante (p.51). Por fim, Sloterdijk reconhece Nietzsche somente como "designer de moda", da "onda individualista", como "marca de um estilo de vida (Life-Style)": "apenas palhaço, apenas poeta, apenas marqueteiro" (p. 54 e 57). E não filósofo?

${ }^{5}$ Cf. SCHOLZ, Peter. Der Prozeß gegen Sokrates. Ein "Sündenfall" der athenischen Demokratie? In: BURCKHARDT, Leonhard; UNGERN-STERNBERG, Jürgen von (Hg.). Große Prozesse im antiken Athen. München, 2000. p. 156-173, aqui, 170. 
Acima de tudo, foi contra Sócrates que Nietzsche se posicionou ${ }^{6}$. Contra ele e contra a "moral cristã", a qual, como o pensador alemão quis revelar, deveu sua força de convencimento fundamentalmente ao ateniense. Com sua própria transvaloração, Nietzsche coloca-se contra Sócrates e contra a transvaloração histórico-universal socrática, e o pensador alemão faz isso com ironia histórico-universal, com uma sabedoria que se mostra, por sua vez, declaradamente questionável. Seria isso uma presunção?

No penúltimo parágrafo de "Por que sou um destino", Nietzsche descreve sua "tarefa":

O descobrimento da moral cristã é um acontecimento que não tem igual, uma verdadeira catástrofe. Quem a coloca a descoberto é uma force majeure, um destino - ele parte a história da humanidade em dois. Vive-se antes dele, vive-se depois dele... O raio da verdade fulminou precisamente o que até então era do mais alto valor: quem compreende o que foi destruído, que veja se ainda lhe resta algo nas mãos. (Ecce Homo, Por que sou um destino, §8) ${ }^{7}$.

Pode-se tomar esse trecho tanto como declarações de um demente, megalomaníaco, ou ainda como uma autoexaltação fanática ${ }^{8}$. O próprio Nietzsche considerou tal possibilidade e respondeu a ela, em Ecce Homo: “[...] em vão procure-se em meu ser um traço de fanatismo. Não se poderá demonstrar qualquer postura presunçosa e patética em nenhum instante de minha vida" (Ecce Homo, Por que sou tão inteligente, §10). Sua presunção

\footnotetext{
${ }^{6}$ Cf. Fragmento póstumo do verão de 1875, em Kritische Studienausgabe (KSA) Vol 8, 6[3]. p. 97: "Sócrates, apenas para admitir, está tão próximo de mim, que eu quase sempre combato contra ele", e ainda sobre isso, cf. MÜLLER, Enrico. Die Griechen im Denken Nietzsches. Berlin/New York: Walter de Gruyter, 2005. p. 188-220 (Monographien und Texte zur Nietzsche-Forschung, Vol 50).

${ }^{7}$ Nota do tradutor: A tradução desta citação é de nossa própria autoria.

${ }^{8}$ Em vista dos tons exageradamente fortes de Ecce Homo, Franz Overbeck, assim como outros mais tarde, tomou Nietzsche por louco já em outubro de 1888, quando o livro apareceu (e também Giorgio Colli, em seu posfácio do volume com os fragmentos de 1888 da edição crítica das obras de Nietzsche, KSA 6, p. 450-458). Sigmund Freud, no entanto, não. Cf. seu conhecido comentário na Sociedade Psicológica das Quartas-Feiras, do dia 28 de outubro de 1908, sobre o recém-aparecido Ecce Homo: "[Nos casos] Onde a paralisia acometeu grandes espíritos, realizações extraordinárias são obtidas até pouco antes da doença (Maupassant). O sinal para isso, que este trabalho de Nietzsche seja considerado como sério e válido, nos oferece a conservação da maestria na forma" (NURNBERG, Herman; FEDERN, Ernst (Hg.). Protokolle der Wiener Psychoanalystischen Vereinigung. Frankfurt am Main 1976-1981, vol. 2, p. 56). Karl Jaspers se expressou de maneira semelhante, com um juízo simultaneamente filosófico e técnico-psiquiátrico (Nietzsche. Einführung in das Verständnis seines Philosophierens. Berlin, 1936, p. 92). Walter Kaufmann, em sua introdução a Ecce Homo (On the Genealogy of Morals, trans. by Walter Kaufmann and R. J. Hollingdale. Ecce Homo, trans. by Walter Kaufmann, by Friedrich Nietzsche. New York 1967, p. 202), não viu no "auto-retrato de Nietzsche nenhuma prova de insanidade, mas um triunfo do estilo - de uma composição com as melhores pinturas daquele tempo." Também Mazzino Montinari, o rígido crítico de textos, concorda com ele: "[...] não se deve partir do fato de uma loucura que espreitava logo adiante para arrancar qualquer chave precipitada para tudo aquilo
} 
de uma fatídica transvaloração de todos os valores coloca-se contra aquilo que ele, por sua vez, "descobriu" como sendo uma presunção: as transvalorações socrática e cristã, que se mantiveram por milênios. Sua transvaloração não era para ser mais do que esse "descobrimento", a revelação da transvaloração cristã. Importava menos elevar a transvaloração nietzscheana ao divino, do que trazer de volta para a dimensão humana, demasiado humana, as transvalorações socrática e cristã, que buscam sua justificação em Deus.

Na medida em que Nietzsche — numa ironia histórico-universal — se eleva ao parâmetro divino, ele faz com que o suposto parâmetro divino se deixe reconhecer como sendo humano. Nesse sentido, os últimos escritos do filósofo, por mais chocantes que possam soar, por mais megalomaníacos

que Nietzsche fez antes de perder o mundo e a própria identidade (como aconteceu por volta de 4 de janeiro de 1889 nas chamadas cartas da loucura). A esse respeito, por exemplo, veja-se a clareza com a qual Nietzsche, de Turim, acompanhava e dirigia Nietzsche contra Wagner e Ecce Homo. Suas inúmeras modificações e acréscimos se encaixam completamente — sem nenhuma exceção — nos dois manuscritos para impressão ou nas páginas de correções; elas estão em uma relação absolutamente lógica uma com a outra. Nietzsche seguramente perdeu sua 'consciência de escritor' por último" (MONTINARI, Mazzino. Ein neuer Abschnitt in Nietzsches "Ecce Homo", in: NietzscheStudien 1 (1972), p. 380-418. aqui, p. 389.). Cf. ainda do próprio autor Philosophie der Fluktuanz. Dilthey und Nietzsche. Göttingen, 1992, p. 339s. e também do próprio autor Nietzsches Kritik der Vernunft seines Lebens, p. 165-167, KORNBERBER, Martin. Zur Genealogie des "Ecce Homo", in: Nietzsche-Studien 27 (1998), p. 319-338, aqui p. 324s, e LANGER, Daniela. Wie man wird, was man schreibt. Sprache, Subjekt und Autobiographie bei Nietzsche und Barthes, in: Zur Genealogie des Schreibens, Bd. 4, hg. von Martin Stingelin, München: 2005, p. 96-100. Nietzsche, ainda como jovem professor de filologia clássica, também se expressou de modo muito presunçoso, no entender de seus contemporâneos, com O Nascimento da Tragédia. Na época em que terminou a terceira parte de Assim falou Zaratustra, ele escreveu a Overbeck: "Eu quero tanto de mim, que sou ingrato com aquilo de melhor que já fiz; e se eu não conseguir impulsionar meus feitos adiante ao ponto de milênios inteiros fazerem seus juramentos mais altos em meu nome, então, do meu ponto de vista, não terei alcançado nada. Por hora - eu anda não tenho nem um único discípulo" (Nietzsche para Franz Overbeck, 21 de maio de 1884, KSB 6, Nr. 513, p. 505s). Quando então, com Ecce Homo e O Anticristo, ele viu sua tarefa levada a cabo e sua obra chegar a uma conclusão - sem poder saber que esse também era o fim de todos os seus feitos - , ele impeliu (ironicamente?) a presunção ao máximo. Expandir aqui a fronteira do que é permitido — da presunção permitida —, poderia, por sua vez, ser uma presunção. As pessoas tomam-se a si próprias como critério para demarcar o que em Nietzsche pode valer como aceitável, presunçoso e megalomaníaco, e colocam sua loucura no momento onde elas não mais o compreendem, não mais o suportam — isso pode começar já n'O Nascimento da Tragédia e vai se aproximando cada vez mais, em Assim falou Zaratustra, em Para a Genealogia da Moral, no Crepúsculo dos Ídolos e em Ecce Homo e O Anticristo. Mas o próprio Nietzsche mediu "a fortaleza de um espírito [...] pelo quanto de 'verdade' ele ainda suportasse, ou, mais claramente, pelo grau em que ele necessitasse vê-la diluída, edulcorada, encoberta, amolecida, falseada" (Além de Bem e Mal, §39) - e igualmente a sua "verdade". Por isso, ECCe Homo poderia ser, segundo Sarah Kofman, em Explosion I, p. 25s, menos um atestado da "loucura" de Nietzsche do que - em referência a tudo aquilo de excêntrico que ocorreu com ele - uma defesa contra a acusação de loucura (veja também Explosions II, da mesma autora, p. 380, onde Kofman procura reconhecer na "'loucura' de Nietzsche" um "rancor da grandeza, uma espécie de exílio interior ao qual o condenava o ciúme dos deuses, um análogo do ostracismo dos gregos"). Sobre a tematização da loucura, na obra de Sarah Kofman (e Lacoue-Labarthes), cf. a resenha de Explosion por Duncan Large, in: The Journal of Nietzsche Studies 8 (1994), p. 129-134, aqui, p. 131. 
que possam parecer, poderiam ainda assim ser levados a sério. O tom desses escritos pode talvez assustar, porque ele sobressalta dos parâmetros divinos, que, por milhares de anos, foram considerados naturais e evidentes.

No primeiro aforismo do capítulo "Por que sou um destino", o qual dá o tom para o restante da seção, Nietzsche explica o que significa para ele ser um destino. Como constantemente ocorre em seus escritos, os tons elevados com os quais ele fala de si devem ressaltar diferenças sutis. O pensador se expressa com grande paixão — e, simultaneamente, de maneira irônica ${ }^{9}$ — trabalhando como se fizesse anotações para si próprio, consciente da "magia dos extremos"10 , e é por isso que um aforismo como o $\$ 1$ do capítulo "Por que sou um destino" de EcCe Homo apresenta problemas metódicos de interpretação. Pelo fato de o pensamento de Nietzsche não se deixar medir pelos parâmetros que questiona, é preciso se arriscar a aderir experimentalmente aos seus próprios parâmetros, o que, no entanto, não deixa de ter consequências.

Conforme sua sentença de que "todos os conceitos em que um processo inteiro se condensa semioticamente se subtraem à definição; definível é apenas aquilo que não tem história" (Para a Genealogia da Moral, II, §13), Nietzsche evitou definições fixas. E ainda, contrariamente à imagem criada pela compilação de fragmentos A Vontade de Poder, o filósofo não apresentou quaisquer resultados conclusivos para sua filosofia.

Mesmo em textos onde ele formulou esses resultados experimentalmente para si, como, por exemplo, no fragmento Lenzer Heide, era evidente que ele não tinha a intenção de publicá-los ${ }^{11}$. Assim como mais tarde Wittgenstein, Nietzsche procurou continuamente trazer conceitos filosóficos aparentemente inequívocos de volta para o seu uso cotidiano e

\footnotetext{
${ }^{9}$ Sobre os variados modos de ironia, em (Sócrates, Kierkegaard e) Nietzsche, cf. HOWEY, Richard Lowell. Some Reflections on Irony in Nietzsche, in: Nietzsche-Studien 4 (1975), p. 36-51. Alexander Nehamas, em Nietzsche: Life as Literature. London: Harvard University Press, 1985, nota que a ironia, que em Sócrates "é dizer 'muito pouco', é a hipérbole em Nietzsche, ou seja, dizer 'demais'." Em Nietzsche, contudo, a hipérbole irônica também é possível.

${ }^{10} \mathrm{Cf}$. Fragmento póstumo do inverno de 1887, KSA 12, 10[94] p. 510: "O feitiço que luta por nós; o olho da Vênus que cega nossos oponentes e os apanha em armadilhas, isto é a magia dos extremos, a sedução, que tudo pratica até o extremo: nós somos imoralistas — nós somos os mais extremos..."

${ }^{11}$ Fragmento póstumo de 10 de junho de 1887, KSA 12, 5[71]. P. 211-217. ("O nilismo europeu", Lenzer Heide). As dissertações de Para a Genealogia da Moral, que Nietzsche redigiu logo depois desse fragmento, foram interrompidas no ponto onde, no fragmento, o pensador havia sistematicamente relacionado suas reflexões sobre o Nilismo, a Vontade de Poder e o Eterno Retorno uma com a outra. Cf. do próprio autor Nietzsches "Genealogie der Moral". Werkinterpretation, Darmstadt 1994, p. 49-53.
} 
para as múltiplas margens de manobra ${ }^{12}$ e, acima de tudo, procurou também trazer o pensamento, das ilusões metafísicas, de volta para "terapias"13.

Em Nietzsche, os conceitos são sempre utilizados em um contexto específico que lhes fornece um sentido específico; sendo que, em contextos alternativos, eles recebem um sentido alternativo. Portanto, uma interpretação metódica e reflexiva dos textos de Nietzsche deve perseguir os contextos nos quais ele utiliza os seus conceitos e desenvolver o processo semiótico no qual eles possivelmente recebem novos sentidos. Apenas esse método, por mais demorado e amplo que possa ser, assegura uma exploração metódica da filosofia de Nietzsche, que segue a exigência metódica do próprio filósofo de que se leia seus escritos "lentamente" e em seu próprio contexto, sem extrair deles "doutrinas" gerais e apressadas ${ }^{14}$.

Tentaremos esclarecer os conceitos do aforismo em questão no seu contexto próprio, no contexto de Ecce Homo e no contexto da obra de Nietzsche como um todo. Faremos ainda uso de anotações não publicadas de Nietzsche, na medida em que elas contribuírem para a compreensão do texto, desfazendo também com isso aparentes ambivalências ${ }^{15}$.

${ }_{12}$ Nota do tradutor: O termo original é Spielraum, e tem o sentido de um espaço de mobilidade semântica no qual uma mesma palavra pode, sob determinadas condições, assumir variações no seu significado.

${ }^{13}$ Cf. WITTGENSTEIN, Ludwig. Investigações filosóficas. § 113 e §116.

${ }^{14}$ Cf. do próprio autor, Nach Montinari. Zur Nietzsche-Philologie, in: Nietzsche-Studien 36 (2007). p. 80-94. Aqui, p. 80-82

${ }^{15} \mathrm{Cf}$. idem, p. 88s. - O aforismo é cheio de fórmulas e frases que são citadas continuamente, mas de maneira isolada e assim se tornam pedaços deslocados da identidade filosófica de Nietzsche ("Eu não sou um homem, sou dinamite.", "Talvez eu seja um bufão...", "pois até agora chamou-se à mentira verdade", "um ato de suprema auto-gnose da humanidade", "que eu seja o primeiro homem decente", "Eu contradigo como nunca foi contradito", "Eu sou um mensageiro alegre, como nunca houve", "Somente a partir de mim haverá grande política na Terra"). Ele raramente é interpretado contextualmente. O comentário de Walter Kaufmann, na sua tradução de Ecce Homo (p. 326), contém apenas duas escassas observações históricas. Thomas Steinbuch, em A Commentary on Nietzsche's ECCe Homo. Lanham/New York/London, 1994, restringe-se ao capítulo "Por que sou tão sábio" e àquilo que ele reconhece como "dinâmica interna", "crescimento da vida nele mesmo" (p. 4s), "liberdade da vida", "excedente de vida nele mesmo" (p. 8), "superfluidade da vida", "grande plenitude da vida" (p. 9). Sarah Kofman, no contexto de sua interpretação completa de Ecce Homo, também desenvolveu inúmeras referências do §1 de "Por que sou um destino" com o livro como um todo e também com a obra de Nietzsche, mas também com Hegel (Explosions II, p. 341-349), sem que as modernas possibilidades de pesquisa textual estivessem disponíveis a ela; com isso, ela chegou, como ela escreve no final, a uma relação "simbiótica" com Nietzsche, aprendeu a "amá-lo" no curso do trabalho de interpretação, puxando para lá e para cá entre ele e Freud (idem, p. 371s). Daniela Langer, em Wie man wird, was man schreibt, oferece em sua dissertação de teoria literária de Kiel (p. 120-130) uma análise da retórica do aforismo, sobretudo da simetria das estruturas, das construções conceituais antitéticas e das peculiaridades sintáticas. 


\section{2 §1 do capítulo "Por que sou um destino," de Ecce Homo}

Nietzsche usa o conceito "destino" apenas no título desta seção e não no próprio aforismo, onde ele fala de "sina" e "fatalidade"16. O filósofo emprega o termo "destino" mais de cem vezes em seus escritos, primeiramente referindo-se ao destino do herói trágico, em seguida, ao destino da formação e da cultura alemãs e, finalmente, no sentido de um acontecimento imprevisível e inalterável, ao qual podem ser submetidos povos e Estados, instituições e valores e, por fim, também religiões e filosofias.

Já cedo Nietzsche anotou em seus registros: "O destino do filósofo é pensar"17. Ao mesmo tempo, contudo, ele permanece cético com relação ao conceito de destino ${ }^{18}$ : “'destino' é um conceito que fazemos com base em um acontecimento imprevisível e inalterável para identificar (e muitas vezes também personificar) aquilo que não é identificável. O conceito define o indefinível, e na medida em que faz isso, é um conceito paradoxal. Mas na medida em que o imprevisível e o inalterável são determinados conscientemente, pode-se também 'representar um destino' e com isso 'ser um destino' para alguém ou algo ${ }^{19}$. Nesse sentido, como filósofo, pode-se ser um destino quando se colocam em dúvida conceitos e convicções sobre os quais até então construímos nossa vida com naturalidade e quando se aportam novos valores para discussão sobre os quais possamos construí-la.

Zaratustra quer ser um destino dessa maneira, e esse querer se transforma no seu destino. ${ }^{20}$ De acordo com o conceito tradicional, o destino é involuntário, é "fatal". Querer seu destino torna ainda mais paradoxal o conceito de destino, que então não abrange apenas o indefinível, mas ao mesmo tempo também o involuntário e o desejado. Nietzsche faz com que


por fim, com tristeza. Pois muito bem! Estou pronto. Começou, agora, a minha última solidão. / Ah, esse negro e triste mar embaixo de mim! Ah, essa pejada expressão noturna! Ah, destino e mar! Para vós cumpre-me, agora, descer! / Eis-me diante do mais alto dentre os meus montes e da mais longa das minhas peregrinações; por isso, preciso descer, primeiro, mais fundo do que algum dia já desci. / - mais fundo na dor do que algum dia já desci, e até dentro de sua mais negra vaga! Assim quer o meu destino. Muito bem! Estou pronto." O trecho foi certamente um modelo para o §1 de "Por que sou um destino."

${ }^{17}$ Cf. Fragmento póstumo da primavera-verão de 1877, KSA 8, 22[95] p.397. "Se o pensar for teu destino, então venera este destino com honras divinas e sacrifica a ele aquilo de melhor, aquilo que mais amas."

${ }^{18}$ Cf. Fragmento póstumo do final de 1876-verão de 1877, KSA 8, 23[163] p. 464. "Se em algum momento existiram palavras, assim crêem os homens, algo deve corresponder a elas, p. Ex.: Alma Deus Vontade Destino etc."

${ }^{19}$ Cf. A Gaia Ciência, $\$ 338$ e Fragmento póstumo do verão-outono de 1882, KSA 10, 2[9] p. 45.

${ }^{20} \mathrm{Cf}$. Assim falou Zaratustra, II, Nas ilhas bem-aventuradas. "Mas assim quer a minha vontade criadora, o meu destino. Ou, para falar-vos mais honestamente: tal destino, justamente - é o que quer a minha vontade."
} 
Zaratustra chame o destino como uma "vivência", algo que é vivenciado, mas que não pode ser conceitualizado. ${ }^{21}$ Quando se aceita o involuntário, não se opõe mais a ele a própria vontade, de sorte que se pode estar "vitorioso e com passo firme [...] em pé no seu destino."22

O "indivíduo soberano", que Nietzsche concebe, em Para a Genealogia da Moral, nesse sentido, pode fazer uma promessa, "porque ele sabe que é forte o bastante para mantê-la contra o que for adverso, mesmo 'contra o destino'" (Para a Genealogia da Moral, II, §2). Soberano é aquele que pode fazer, de tudo aquilo que lhe sucede, algo que ele próprio deseja. E os homens que querem seu destino podem, eles próprios, atuarem como um destino. Eles vêm "como o destino, sem motivo, razão, consideração, pretexto, eles surgem como o raio, de maneira demasiado terrível, repentina, persuasiva, demasiado 'outra', para serem sequer odiados" (Para a Genealogia da Moral, II, §17). O destino é sem razão e sem motivos aparentes, tampouco é passível de ser conceitualizado racionalmente, a partir de conceitos gerais, e, na medida em que uma pessoa quer o destino, ela igualmente deixa de ser conceitualizável racionalmente. Todavia, mesmo assim, ela pode dar uma razão — sua razão - ao seu destino. É dessa maneira que Nietzsche se apresenta no final de Ecce Homo. Ele chama de "destino" à sua "tarefa" que ele voluntariamente assume (Ecce Homo, Por que sou tão inteligente, §9). O destino torna "grande" a tarefa de atar um "nó" no "destino da humanidade" (Ecce Homo, Assim falou Zaratustra, §5) e, uma vez que isso coube a ele, ele também o quer.

O processo semiótico no conceito de destino em Nietzsche parte dele próprio e culmina em seu próprio destino. Processo semelhante será visto, na sequência, repetidas vezes. Os conceitos de Nietzsche se desenvolvem de tal modo que o pensador pode, no fim, compreender-se a si próprio, a partir deles. No § 1 de Ecce Homo, Por que sou um destino, que mal ocupa uma página na KSA, o pensador converge todos os grandes temas da filosofia ocidental — destino, religião, verdade e política — em um único ponto: ele próprio e sua transvaloração de todos os valores.

Começo, pois, a exegese do aforismo, passo a passo.

[1] Conheço a minha sina. [2] Um dia, meu nome será ligado à lembrança de algo tremendo, [3] — de uma crise como jamais houve

\footnotetext{
${ }^{21}$ Cf. Assim falou Zaratustra III, O viandante.

${ }^{22}$ Assim falou Zaratustra III, Da bem-aventurança a contragosto. Zaratustra alerta contra a "ilusão" de um destino fatal (Das velhas e novas tábuas §9): quando não se quer sucumbir ao destino, é preciso ser tão duro e inexorável quanto ele — com o que se aceita o imutável como sua própria vontade (idem, $\$ 29$ e §30.). Do mesmo modo, os animais (e apenas eles) falam a Zaratustra que "seu destino" é ser o mestre do eterno retorno (O convalescente), e Zaratustra responde ao Papa "sem ofício": "É melhor não termos nenhum Deus, é melhor forjarmos o destino com as nossas próprias mãos, é melhor sermos doidos, é melhor sermos Deus nós mesmos!" (Sem ofício).
} 
sobre a Terra, da mais profunda colisão de consciências, de uma decisão conjurada contra tudo o que até então foi acreditado, santificado, requerido. [4] Eu não sou um homem, sou dinamite. [5] — E com tudo isso nada tenho de fundador de religião - [6] religiões são assunto da plebe, [7] eu sinto necessidade de lavar as mãos após o contato com pessoas religiosas... [8] Não quero "crentes", penso ${ }^{23}$ ser demasiado malicioso para crer em mim mesmo, nunca me dirijo às massas... [9] Tenho um medo pavoroso de que um dia me declarem santo: perceberão por que publico este livro antes, ele deve evitar que se cometam abusos comigo... [10] Eu não quero ser um santo, seria antes um bufão... Talvez eu seja um bufão... [11] E apesar disso, ou melhor, não apesar disso pois até o momento nada houve mais mendaz do que os santos - , a verdade fala em mim. — [12] Mas a minha verdade é terrível: pois até agora chamou-se à mentira verdade. - [13] Transvaloração de todos os valores: eis a minha fórmula para um ato de suprema auto-gnose da humanidade, [14] que em mim se fez gênio e carne. [15] Minha sina quer que eu seja o primeiro homem decente, [16] que eu me veja em oposição à mendacidade de milênios... [17] Eu fui o primeiro a descobrir a verdade, ao sentir por primeiro a mentira como mentira ao cheirar... [18] Meu gênio está nas narinas... [19] Eu contradigo como nunca foi contradito, e sou contudo o oposto de um espírito negador. [20] Eu sou um mensageiro alegre, como nunca houve, eu conheço tarefas de uma altura tal que até então inexistiu noção para elas, somente a partir de mim há novamente esperanças. [21] Com tudo isso sou necessariamente também o homem da fatalidade. [22] Pois quando a verdade sair em luta contra a mentira de milênios, teremos comoções, um espasmo de terremotos, um descolamento de montes e vales como jamais foi sonhado. A noção de política estará então completamente dissolvida em uma guerra dos espíritos, todas as formações de poder da velha sociedade terão explodido pelos ares todas se baseiam inteiramente na mentira: haverá guerras como ainda não houve sobre a Terra. Somente a partir de mim haverá grande política na Terra. (Ecce Homo, Por que sou um destino, §1).

[1] O texto inicia-se com provocações. A palavra "conheço" "Conheço a minha sina") gera a expectativa de um conhecimento seguro. Mas não se pode verdadeiramente conhecer uma "sina" (Loos): a palavra "sorte" (LoS) acentua o caráter fortuito e inatingível do destino. Quem se arroga conhecer sua sorte, porta-se como um profeta. Contudo, os profetas (pelo menos aqueles do Velho Testamento) não predizem tanto o destino, mas sobretudo veem e anunciam — contra a inércia da superficialidade cotidiana — aquilo

\footnotetext{
${ }^{23}$ Nota do tradutor: Optamos por empregar o termo "penso" - ao invés de "creio", como foi a escolha de Paulo C. de Souza - para a expressão ich denke.
} 
que já começou a acontecer e o que disso deve seguir (os profetas bíblicos, em sua maioria, anunciam a corrupção do povo escolhido de Deus). ${ }^{24}$

Nietzsche, que viu e anunciou a "morte de Deus" para o seu tempo, quer mostrar as consequências que muito provavelmente ocorrerão, sendo que ele já o fizera antes — de modo mais espetacular em Assim falou Zaratustra, e antes e depois desse livro, nos aforismos 125 e 343 da Gaia Ciência — sem, no entanto, conseguir ser suficientemente ouvido. Sua sorte foi e é a de ser (no duplo sentido) um profeta inaudito. Através da genealogia de seu pensamento, levada a cabo nas seções anteriores de Ecce Homo, Nietzsche torna patente sua sorte a partir das condições fortuitas de sua vida, que se ajustaram a um destino inevitável, necessário: de ser, com a sua "descoberta", um "destino da humanidade".

[2] "Um dia, meu nome será ligado à lembrança de algo tremendo". Nietzsche novamente prossegue com aparente certeza. Contudo, o fato de ele vir a se tornar um destino em algum tempo indeterminado depende de outros o reconhecerem como um destino. Em outras palavras, seu destino somente "se realizará" quando outros também considerarem o destino do filósofo como sendo o deles. Vai depender da lembrança futura de seu nome. Depende de ser lembrado novamente e de o deixarem ser passado adiante; a lembrança alheia é seu destino ${ }^{25}$.

${ }^{24}$ Os profetas bíblicos quase não falam de destino, mas sim da vontade do povo de Deus, que irá ou não se alinhar com a vontade de Deus. Cf. BERNFELD, Simon; BAMBERGER, Fritz (Hg.), Die Lehren des Judentums nach den Quellen. Leipzig 1928-1930, neue und erweiterte Ausgabe München/ Darmstadt, 1999, Vol. 1, p. 75

${ }^{25}$ Não apenas no âmbito de conhecimento aberto, mas na própria pesquisa acadêmica de Nietzsche, "uma desorientadora sucessão de 'novos Nietzsches'" prenderam-se ao nome de Nietzsche (ANSELLPEARSON, Keith; CAYGILL, Howard. On the Fate of the New Nietzsche, in: ANSELL-PEARSON; CAYGILL (Ed.). The fate of the new Nietzsche. Aldershot u.a., 1993, p. 1-11. aqui, p. 1), os quais deveriam ser sempre outros, mas também sempre os verdadeiros, os únicos justificados ou, nas palavras de Zaratustra, os "últimos". A filosofia de Nietzsche (e qualquer "identidade", sobretudo também a identidade dos homens) será então agora "confundida", quando se quiser "determiná-la". Nietzsche, que introduziu ECCe Homo com a suplicante exigência: "Ouçam-me! Pois sou tal e tal. Sobretudo não me confundam!" (Ecce Homo, Prólogo, §1), poderia ao mesmo tempo, como um teste para seus leitores, ter também pretendido em Ecce Homo que eles o confundissem e que, por meio disso, se comprometessem com ele; fazendo isso por meio de uma notória "autoparódia" — segundo Daniel Conway, em Nietzsche's Doppelgänger: Affirmation and Resentment in ECCe Homo, in: ANSELLPEARSON, Keith; CAYGILL, Howard. (Ed.). The fate of the new Nietzsche, p. 55-78 -, que zomba de todas as tentativas de lhe atribuir um verdadeiro "si". Em sua contribuição belicosa, Conway tem por alvo a idolatria, a qual, de seu ponto de vista, Alexander Nehamas e Richard Rorty realizaram com Nietzsche e especialmente com ECCe Homo, que ele critica fortemente; por fim, ele próprio insiste em um verdadeiro Nietzsche, agora um "bufão fragmentado, ressentido, que anseia pelo fim" (p. 68). Como mote, ele apresenta a sentença de Nietzsche, de Para a Genealogia da Moral, III. §19: "Moral: que homem prudente escreveria hoje uma palavra honesta sobre si? - para isso, teria que pertencer à Ordem da Santa Temeridade." Mas aqui ele novamente elimina a palavra "moral": segundo Nietzsche, ela é a moral dos senhores, que torna necessário o jogo de máscaras, que impede autorrepresentações "destemidas" - e que para isso exige, nesse momento, o próprio Nietzsche. 
Um nome, por sua vez, é um signo geralmente utilizado para um indivíduo, e lhe é dado por outros indivíduos antes que ele próprio possa falar e dizer "eu". O nome é um signo estranho, que o indivíduo (na maioria das vezes) usa como seu, para se identificar frente a outros. Desse modo, um nome igualmente é um destino que se apropria para si. Tudo aquilo que ocorrer com o portador do nome cristaliza-se no próprio nome. O nome tornase "conceito" 26 e perdura por tanto tempo quanto alguém se lembrar dele ${ }^{27}$.

Com isso, a lembrança de um nome é o destino de um destino que outros precisam querer, pois as pessoas se lembram apenas daquilo que querem lembrar ou daquilo que se veem obrigadas a lembrar. Nietzsche elabora seu destino sobre essa coação: com aforismos como este que estamos analisando, o filósofo quer assegurar tanto que seu nome seja lembrado, como ainda que se tenha de lembrar que não se pode esquecer daquilo que foi escrito nesse nome.

[3] Desde então, não se pode de fato esquecer-se do nome Nietzsche. Mesmo seus opositores atribuem a ele "algo tremendo", "uma crise como jamais houve sobre a Terra, [...] a mais profunda colisão de consciências, [...] uma decisão conjurada contra tudo o que até então foi acreditado, santificado, requerido". Dentre outros leitores, Jürgen Habermas entende a repercussão de Nietzsche ${ }^{28}$ justamente desse modo, pois julga que Nietzsche seria tão perigoso quanto ele próprio se julgava. Contudo, o filósofo de

\footnotetext{
${ }^{26}$ Cf. do próprio autor. Philosophie der Orientierung. Berlin/New York, 2008, p. 282-285 e 346-351.

${ }^{27}$ Jacques Derrida, em Otobiographien, leu ECCe Homo dentro da totalidade da "política de nomes próprios" de Nietzsche. Nietzsche seria o primeiro na Filosofia que lidou com essa decidibilidade "de filosofia e vida, de ciência e filosofia da vida com seu nome, em seu nome" (p. 24), e ele ligou uma "lógica do morto" com a "lógica do vivo" no signo desse nome (p. 36). Os nomes também morrem mas, acima de tudo, morre-se "antes do seu nome" (p. 51). Derrida cita o \$1 de "Por que sou um destino" na totalidade — no contexto da pergunta sobre o quanto a "grande política" — com a qual o aforismo termina - se envolve com a política do nacional-socialismo, o qual, por direito ou não, reclamou para si o nome de Nietzsche (p. 54).

${ }^{28}$ Nietzsche seria o "centro giratório" que deturpou o "discurso da modernidade", com o "objetivo" de explodir o invólucro racional da modernidade" (Nota do tradutor: HABERMAS, Jürgen. O Discurso filosófico da modernidade. São Paulo: Martins Fontes, 2000). Nietzsche acelerou a "intensificação do subjetivo até o completo autoesquecimento", "as categorias das ações e pensamentos sensatos" estariam "desmoronadas" para ele, e, com isso, a modernidade estaria privada de "seu conteúdo emancipatório" e "empurrada para o irracional, metafísico" (idem, p. 116s). Nietzsche impulsionou a "destruição da razão", como Georg Lukács a denominou (LUKÁCS, Georg. A destruição da razão Berlin, 1954, agora, em: Obras completas, vol. 9, Newied/Berlim 1962). Nietzsche criticou o conceito metafísico da razão (Cf. sobretudo Crepúsculo dos Ídolos, A "razão" na filosofia), mas simultaneamente desenvolveu um novo conceito bem diferenciado de razão, o qual até agora ainda não foi desenvolvido em seu contexto pelas pesquisas de Nietzsche. Acerca da crítica da crítica de Lukács a Nietzsche, cf. OTTMANN, Henning. Anti-Lukács. Eine Kritik der Nietzsche-Kritik von Georg Lukács. In: NietzscheStudien 13 (1984), p. 570-586. E, do mesmo autor, Philosophie und Politik bei Nietzsche. 2. ed. revisada e ampliada. Berlin/New York 1999, p. 429-433 (Monographien und Texte zur Nietzsche-Forschung, vol 17). Acerca da discussão da crítica de Habermas a Nietzsche, cf. SEDGWICK, Peter. Nietzsche, Normativity and Will to Power. Nietzsche-Studien 36 (2007), p. 201-229.
} 
Naumburg apenas "revelou" que, no que diz respeito à razão na filosofia ocidental, trata-se de uma "contrafactualidade" — ou seja, o fato não mais pode ser tomado como critério de justificação de um discurso - que, em outras palavras, a razão era objeto de uma crença que agora - também para Habermas - perdeu sua autoevidência. Depois de Nietzsche, pode-se ter necessidade ou não dessa crença; aqueles que são incapazes de viver sem ela não poderão fazer mais do que rejeitar as impertinências de Nietzsche. Contudo, aquele que se arriscar a tomar parte em seu "esclarecimento" se encontrará na "mais profunda colisão de consciências" — que é justamente o que o filósofo esperava.

Kant concebeu sua "crítica" da razão na consciência de que a razão — que, ao longo dos séculos, ultrapassou seus limites e entrou com isso em um mero "tatear às cegas" em meio a crenças metafísicas indemonstráveis - apenas alcançaria o "caminho seguro das ciências" através do estabelecimento seguro dos seus limites. ${ }^{29}$ A razão permanecia aqui ainda como uma instância da própria crítica e, enquanto tal, ainda estava elevada acima da experiência e em condições de fazer juízos a priori, reconhecidamente independentes das condições da vida ou do tempo.

Todavia, mesmo as ideias de que a razão seria independente das condições de vida ou de tempo e de que deveria haver uma razão "pura" corriam, já no século XIX, bastante risco de tornarem-se meras crenças, as quais acabariam por ser cada vez menos críveis. E Nietzsche, que agudamente reconheceu isso, extraiu corajosamente a "perigosa consequência" ${ }^{30}$ : a crítica da razão se transformaria na sua crise e forçaria a uma nova orientação dos fundamentos mesmo na Europa, que até então acreditara firmemente em uma razão eterna.

No entanto, como Nietzsche anotou no fragmento Lenzer-Heide, essa nova orientação levará, em seguida, a uma desorientação massiva, à liberação de forças que, em desespero, só podem e querem destruir. Essa "crise" irá irromper em uma "convulsão", em uma "fúria cega" "de niilismo e vontade de destruição". ${ }^{31}$ A "perigosa consequência" tornou-se profecia: as guerras mundiais, totalitarismos, genocídios e terrorismos, como mostrou o século $\mathrm{XX}$, podem ser compreendidas (ao menos também) como consequências dessa crise espiritual, na qual entraram as convicções fundamentais do

${ }^{29}$ KANT, I. Crítica da Razão Pura. Prefácio à segunda edição, B VII.

${ }^{30} \mathrm{Cf}$. a autoapresentação de Nietzsche, no Fragmento póstumo do início de 1888, KSA 13, 14[25]: "Em que Nietzsche se destaca: a espontaneidade de sua visão psicológica, uma amplidão vertiginosa de seu olhar ao redor, do vivenciado, do adivinhado, desenvolvido, da vontade de consequência, do destemor diante da consequência mais dura e perigosa."

${ }^{31}$ Fragmento póstumo de junho de 1887, KSA 12, 5[71]. 11 e 14. p. 215s. 
pensamento europeu, em especial a convicção do efeito benéfico de toda razão em geral. Desde esse tempo, não podemos mais estar seguros com relação à razão europeia.

[4] Nietzsche empregou a metáfora "dinamite": "Eu não sou um homem, sou dinamite." 32 Com a metáfora dinamite, introduzida pela primeira vez em Além de bem e mal ${ }^{33}$, o filósofo, por um lado, ainda dramatiza a transvaloração. Por outro lado, ele pensa em "uma dinamite do espírito, uma niilina russa recém-descoberta" (Além de Bem e Mal, §208) que permanece despercebida por longo tempo e, de repente, mostra seu efeito. No prólogo de Ecce Homo, ele cita Zaratustra: "As palavras mais silenciosas são as que trazem a tempestade, pensamentos que vêm com os pés de pomba dirigem o mundo - " (EcCe Homo, Prólogo, §4) $)^{34}$. Isso quer dizer que pensamentos podem desenvolver força explosiva — contra pensamentos, podendo demolir relações de pensamentos tidas até então como firmes ${ }^{35}$.

${ }^{32}$ A metáfora da dinamite, como contradição ao conceito de homem, foi a que mais fascinou os intérpretes de Nietzsche - sobretudo Sarah Kofman, que deu a sua interpretação de Ecce Homo o título "Explosions". Ela entende o Nietzsche que aqui se abre como uma explosão repentina de forças há muito acumuladas e, por sua vez, faz com que o texto de Nietzsche, segundo suas próprias palavras, exploda interpretações teimosas e insistentes, justificando desse modo o estranho que há nele ("bem compreendido, em tudo isso não há verdadeiramente nada de louco..." Explosions I, p. 21).

${ }^{33}$ Um jornalista suíço, Dr. J. V. Widmann, ao qual a metáfora da dinamite agradou, traduziu-a em sua resenha crítica de Para além de Bem e Mal no contexto da engenharia suíça: "Cada estoque de dinamite que foi empregado na construção da ferrovia Gotthard foi guiado pela bandeira preta, que indicava o perigo de morte. - Apenas nesse sentido falamos do novo livro do filósofo Nietzsche como um livro perigoso. Não colocamos nesta resenha nenhum traço de repreensão contra o autor e sua obra, não mais do que uma bandeira preta pode repreender qualquer explosivo. Menos ainda poderia nos ocorrer que, por meio do aviso sobre a periculosidade de seu livro, entregássemos o pensador solitário às águias do altar (Altarkrähen) e aos corvos do púlpito (Kanzelraben). O explosivo do espírito, assim como o explosivo material, pode servir a uma obra bem útil; não é necessário que ele seja mal empregado em intentos criminosos. Age-se bem simplesmente ao dizer claramente 'aqui há dinamite! onde este material estiver estocado... Nietzsche é o primeiro que conhece uma nova saída, mas uma tão terrível que normalmente se assusta quando se vê ele mudar a única trilha até então não pisada!..." (Folha de Berna, de 16 e 17 de setembro de 1886, citado por Montinari em: Chronik zu Nietzsches Leben, KSA 15, p. 160s. Cf. KRUMMEL, Richard Frank com a participação de KRUMMEL, Evelyn. Nietzsche und der deutsche Geist, vol 1: Ausbreitung und Wirkung des Nietzscheschen Werkes im deutschen Sprachraum bis zum Todesjahr. Ein Schrifttumsverzeichnis der Jahre 1867-1900. 2. ed. revisada e ampliada. Berlin/New York, 1998, p. 131. Monographien und Texte zur Nietzsche-Forschung, vol 3.) Nietzsche registrou o artigo com alegria (Cf. carta de Nietzsche a Constantin Georg Naumann em Leipzig, 19 de setembro de 1886, KSB 7, Nr. 749, p. 249, e mais as cartas, logo em seguida) e, por sua vez, adotou repetidamente a metáfora - não apenas para o seu próprio filosofar, mas também para o cristianismo, contra o qual ele se dirigia.

${ }^{34}$ Ecce Homo, Prólogo, §4, Cf. Assim falou Zaratustra II, A hora mais silenciosa. - a isso se acrescenta KNOCHE, Michael; ULBRICHT, Justus H · WEBER, Jürgen (Hg .), Zur unterirdischen Wirkung von Dynamit. Vom Umgang Nietzsches mit Büchern zum Umgang mit Nietzsches Büchern. Wiesbaden, 2006.

${ }^{35}$ Vanessa Lemm, em Animality, Creativity and Historicity: A Reading of Friedrich Nietzsche's Vom Nutzen und Nachtheil der Historie für das Leben, in: Nietzsche-Studien 36 (2007), p. 169-200, p. 197 separa (como tantos) a metáfora dinamite do seu contexto e encontra nela "o nascimento explosivo das múltiplas identidades de Nietzsche". Contudo, contra essa linha de interpretação - a qual, ao olhar para Ecce Homo, também já segue, aqui e lá, o escrito de Daniela Langer, Wie man wird, was 
O pensamento da "igualdade das almas diante de Deus" também foi, conforme Nietzsche mostrou n' O Anticristo, § 62, um "explosivo de conceito que afinal se tornou revolução, idéia moderna e princípio decadente de toda a organização social - [foi] dinamite cristã" ${ }^{36}$. O filósofo chama de "dinamite", sem o adendo de "do espírito", a si próprio: "Eu não sou um homem, sou dinamite." A contradição homem-dinamite reside no seguinte perigo: enquanto os homens forem conduzidos pela moral cristã, eles não serão perigosos; mas quando se libertam dela, daí, sim.

[5] Mas a dinamite não tem efeito apenas destrutivo. Quando se aprende como lidar com ela, pode-se destruir obstáculos e criar lugar para construções, ruas, linhas férreas etc., demolindo de maneira precisa aquilo que é velho, para abrir espaço para o novo. O novo, para o qual Nietzsche quer abrir caminho, não poderia ser uma nova religião e moral totalizadora. Ele não quer ser um criador de religiões: "E com tudo isso nada tenho de fundador de religião".

Dizer isso parece trivial, por um lado, e altamente presunçoso, por outro. Entretanto, faz sentido: a forte crise de orientação que a transvaloração dos valores traz consigo faz com que se espere que ela desperte uma necessidade ainda mais forte pela religião. Uma transvaloração de todos os valores, como o pensador a anuncia, deve deflagrar um forte impulso por novas religiões - e nós vivenciamos isso ainda hoje. Segundo Nietzsche, as religiões respondem à necessidade de se lidar facilmente com a totalidade da vida. Contudo, na medida em que elas protegem o homem da verdade da vida, elas também mantêm essa necessidade. Nietzsche, no entanto, diferentemente de outros críticos da religião, não substitui a religião pela verdade, pois ele também foi o crítico mais mordaz da verdade ${ }^{37}$.

Nietzsche entende que a verdade também seria um tipo de erro, para o qual coage a necessidade da vida ${ }^{38}$. E, nas circunstâncias onde esse erro for deliberadamente propagado como verdade, Nietzsche o chama de mentira.

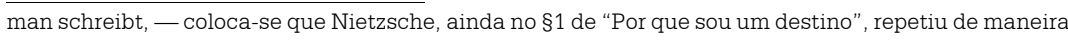
bastante precisa "eu quero", "eu sou", "eu falo", "eu contradigo" (Cf. a resenha da monografia de Daniela Langer por Christof Windgätter, Nietzsches Schreibpraktiken, in: Nietzsche-Studien 35 (2006), p. 407-421, aqui p. 415s.)

${ }^{36}$ Por fim, Nietzsche repete a metáfora múltiplas vezes, em suas cartas. Cf. carta de Nietzsche a Paul Deussen, 26 de novembro de 1888, KSB, 8, Nr. 1159, p. 492, carta a Georg Brandes, início de dezembro de 1888, KSB 8, Nr. 1170, p. 500s, carta a Helen Zimmern, 8 de dezembro de 1888, (rascunho), KSB 8 , Nr. 1180, p. 512, e carta a Heinrich Köselitz, 9 de dezembro de 1888, KSB 8, Nr. 1181, p. 513 (“o superlativo mais elevado da dinamite").

${ }^{37}$ Cf. do próprio autor, Nietzsches Neubestimmung der Wahrheit, in: Nietzsche-Studien 14 (1985), p. 69-95.

${ }^{38}$ Cf. a expressão mais bem formulada em um fragmento póstumo de abril-junho de 1885, KSA 11, 34[253], p. 506, KGW tomo IX 1, p. 4: "Verdade é o tipo de erro, sem o qual um determinado tipo de ser vivo não consegue viver. O valor para a vida decide em última instância". 
Desse modo, ambas - religião e verdade - são, para a maioria das pessoas, erros necessários à vida. Mas, para aquelas pessoas que fundam as verdades e religiões, que buscam aliviar os sofrimentos humanos, aumentando assim seu próprio poder; para essas pessoas, religião e verdade são mentiras. Por isso, os fundadores de religião são "horrendos híbridos de doença e vontade de poder" (Ecce Homo, Prólogo, §4) — também eles foram e são transvaloradores de valores e figuras histórico-universais das mais ativas. Os filósofos se movem perigosamente próximos aos fundadores de religião: a diferença é que eles são apenas menos bem-sucedidos. ${ }^{39}$

[6] Os fundadores de religião têm a capacidade de "dar a essa vida uma interpretação, mediante a qual ela pareça iluminada pelo mais alto valor, de modo a se tornar um bem pelo qual a pessoa luta e, em algumas circunstâncias, dá a própria vida" (A Gaia Ciência, §353). Porém, isso Nietzsche também quis, aproximando-se tanto de um fundador de religião que as pessoas (e talvez também ele próprio) facilmente poderiam tomá-lo como se fosse um deles. Dessa maneira, nesse momento a separação foi difícil, inclusive para ele próprio.

Diante disso, ele faz uso de seu meio mais explícito, a polêmica: "religiões são assunto da plebe". Ele utiliza a expressão "assunto da plebe" apenas aqui. Plebeu é aquele que não quer ser conveniente - e Nietzsche, especialmente, não quer. Por outro lado, no entanto, é difícil separar a plebe das pessoas convenientes. Zaratustra lida incansavelmente com essa delimitação, opondo à plebe os "destacados".

${ }^{39}$ Cf. A Gaia Ciência, §149. "Pitágoras e Platão [...] tiveram tão genuínas almas e aptidões de fundadores de religião, que é impossível não nos admirarmos do seu fracasso: mas eles chegaram apenas a seitas." Veja-se também o fragmento póstumo do verão de 1872 - início de 1873, KSA 7, 19[62], p. 439. "Kant estranho - Sabedoria e Crença! Parentesco íntimo entre filósofos e fundadores de religião!" Houve "Fundadores de seitas" (A Filosofia na Época Trágica dos Gregos §2) particularmente entre os aprendizes de Sócrates (Cf. fragmentos póstumos do verão de 1872 - início de 1873, KSA 7, 19[28], p. 425 e 19[60], p. 438.) Mas: "Nenhum dos grandes filósofos gregos arrastou o povo atrás de si: Empédocles (depois de Pitágoras) foi quem mais tentou, mas também não foi com a filosofia pura, mas sim com um veículo mítico dela. Outros rejeitavam o povo por princípio (Heráclito). Outros tinham por público um círculo bastante destacado de eruditos (Anaxágoras). Sócrates tinha a maior tendência democrático-demagógica: o sucesso são fundações de seitas, também uma prova em contrário. Como poderiam filósofos menores conseguirem o que tais filósofos não conseguiram? Não é possível fundar uma cultura do povo sobre filosofia. Além disso, a filosofia nunca pode ter uma importância fundamental em relação com uma cultura e sempre apenas uma importância parcial. Qual é este?" (fragmento póstumo do inverno de 1872-1873, KSA 7 23[14], p. 544). Como se sabe, Nietzsche também nutria ambições próprias de fundação de seitas, primeiramente no cortejo de Richard Wagner (sua arte "é uma arte sectarista e será uma educação sectarista: mas com as ambições mais altas de ultrapassar as seitas", fragmento póstumo do verão de 1875, KSA 8 , 11[31]), e depois para sua própria filosofia. Cf. fragmento póstumo do início de 1880-início de 1881, KSA 9 , 10[B38], p. 421: "Escolher homens à sua volta, entre os quais se possa apontar e conservar sua humanidade ideal. Primeiramente tornar a tarefa mais fácil para si, e depois cooptar gradativamente homens estranhos para o círculo. - Mas primeiramente criar seu próprio círculo, expulsar outros." Também Zaratustra permite a ele fazer um experimento com discípulos — e falhar com isso. 
Não obstante, há igualmente uma "crença de superioridade" plebeia no erudito que "trata o homem religioso como um tipo inferior e de menor valor, que ele mesmo superou, deixou para trás, para baixo" (Além de Bem e Mal, §58), e há um "instinto plebeu" na "declaração de independência do homem científico", acima de tudo na sua "emancipação da filosofia", como o filósofo a entende.

Também na filosofia há plebeus; pessoas que seguem as verdades e valores dominantes, para obterem boa aceitação e aplausos. O "verdadeiro filósofo", ao contrário, "sente o fardo e a obrigação das mil tentativas e tentações da vida - ele arrisca a si próprio constantemente, jogando o jogo ruim..." (Além de Bem e Mal, §205), ele tem a coragem de ficar sozinho e lança ironias contra todos os conhecimentos ensináveis.

Aqui, Nietzsche duvida por fim de Sócrates - e ainda de si mesmo. Em 1885, ele escreve a Köselitz: "Em todos os meus estados de enfermidade, sinto, com medo, um tipo de impulso baixo para fraquezas plebeias, suavidade plebeia, até mesmo virtudes plebeias — você entende isso? Oh você, o mais saudável!"40

[7] Em meio à polêmica do texto de Ecce Homo, Nietzsche mostra que continua "em contato" com "homens religiosos", não se esquivando deles: "eu sinto necessidade de lavar as mãos após o contato com pessoas religiosas". Dos seus "contatos" com pessoas religiosas, o pensador tem "necessidade" de se manter "limpo" daquilo de "plebeísmo", mas também daquilo de "destacado" que elas vivem. Para tanto, ele próprio precisa lidar, debater-se com isso. Os religiosos o "afetam", pois ele, assim como qualquer outro, não está livre das necessidades religiosas e, principalmente, quando se trata de pessoas que necessitam da religião, ele precisa lutar consigo para não ser subjugado nem dominado por elas e, dessa forma, perder seu distanciamento crítico.

[8] Evidentemente, Nietzsche nem sempre "quer", como ele enfatiza, conseguir o que ele quer ${ }^{41}$. Com suas expressões "Não quero 'crentes'" e "Eu não quero ser um santo" - que parecem levar sua presunção ao tom extremo em provocar - Nietzsche rejeita necessidades religiosas, as quais ele mesmo mal pode evitar. ${ }^{42}$ Para isso, ele remete a fatos de sua

${ }^{40}$ Carta de Nietzsche a Heinrich Köselitz, 23 de julho de 1885, KSB 7, Nr. 613, p. 68. Para a nota mencionada na carta, cf. fragmento póstumo de maio-julho de 1885, KSA 11,.35[76], p. 543.

${ }^{41}$ Nota do tradutor: esta primeira frase - no original: "Er "will", wie er betont, offenbar ohne immer auch zu erreichen, was er will" - é de difícil tradução e significa que Nietzsche, no fundo, nem sempre quer de fato conseguir aquilo que ele diz que "quer".

${ }^{42}$ Também Paul Mirabile, em The Nomadic Thought. Friedrich Nietzsche und Zhuang Zi. Convergences and Divergences, in: Nietzsche-Studien 33 (2004), p. 237-277, aqui p. 270, aconselha a tomar essas palavras "pelo seu valor aparente" e não imputar a Nietzsche "nenhuma intenção de dissimular um profeta ou deus". 
personalidade e aos seus escritos, sobre os quais, por sua vez, ele não está seguro: "penso ser demasiado malicioso para crer em mim mesmo". "Malicioso" não é "mau". Mau é quem faz mal a outros, quem, na perspectiva deles, fere seus olhos. Malicioso, em contraposição, é quem lembra a outros o que de mau está contido neles, que eles próprios não reconhecem: ele as esclarece sobre elas próprias. Como Nietzsche pôde aprender, sobretudo a partir de Voltaire ${ }^{43}$, a malícia é um meio de esclarecimento e, quando se consegue ser malicioso contra si próprio, ela também é um meio de esclarecimento sobre si próprio ${ }^{44}$. Contudo, Nietzsche lança previamente um "penso", o que é de grande significado.

Por sua vez, pode-se compreender isso como "eu creio". "Penso" pode significar em alemão simplesmente "eu creio", de sorte que a frase significaria: "eu creio ser demasiado malicioso para crer em mim mesmo". É patente que a crença se torna paradoxal, pois, se por um lado ela se afirma por si mesma, por outro se torna incerta. Entrementes, a expressão "eu penso" foi o símbolo do esclarecimento moderno, introduzida por Descartes com o objetivo de não deixar restar nenhuma crença sem comprovação. Se alguém lê o "penso" de Nietzsche desse modo, o "ser demasiado malicioso para crer em mim mesmo" torna-se uma explicação do "penso": e, assim, esse pensamento filosófico do esclarecimento consistiria em ser malicioso demais para crer em si mesmo, para dar-se por satisfeito com as certezas que o consenso das massas o tornam seguro. Em resumo: não pensar com as massas, mas por si próprio ("nunca me dirijo às massas").

Todavia, ambas as possibilidades de leitura não se excluem. Mesmo a expressão "eu penso esclarecidamente", "eu penso por mim mesmo", pode ainda ser apenas um "eu creio que, por mim mesmo, posso pensar esclarecidamente". Para um esclarecido, não há certeza sobre essa crença, e a formulação de Nietzsche é particularmente maliciosa a ponto de permitir ambas as leituras, sendo que ambas ainda deixam reconhecer aquilo que ele "quer": crer na própria força de esclarecimento, sem jamais poder estar seguro sobre ela.

\footnotetext{
${ }^{43}$ Ainda em Ecce Homo, Nietzsche presta homenagem à arte destacada de esclarecimento de Voltaire sua "guerra sem pólvora e sem fumaça, sem atitudes guerreiras, sem pathos e membros contraídos (...). Um erro após o outro é calmamente colocado no gelo, o ideal não é refutado - ele congela... Aqui, por exemplo, congela "o gênio"; pouco adiante congela "o santo"; sob um espesso sincelo congela "o herói"; por fim congela "a fé", a chamada "convicção", também a "compaixão" esfria consideravelmente - em quase toda parte congela "a coisa em si"..." (ECCe Homo, Humano, demasiado humano, §1). Cf. também Humano, demasiado humano II, O andarilho e sua sombra, §237.

${ }^{44}$ Em EcCe Homo, Assim falou Zaratustra, §6, Nietzsche caracteriza o "tipo Zaratustra" pela "onipresença de malícia e petulância". Walter Kaufmann, que compreende Nietzsche como contraparte de Sócrates, faz uma ponte para a ironia, a maldade e o cinismo do ateniense.
} 
[9] Em um rascunho desse aforismo, Nietzsche anota logo a seguir: "e com tudo isso nada há em mim de um < faná > tico; quem me conhece me toma por um simples intelectual, talvez um pouco malicioso, <que $>$ sabe ser jovial com todo o mundo. Este livro oferece, como eu espero, uma imagem bem diferente $<$ da $>$ de um profeta (....." Logo adiante, no mesmo rascunho: "Fatídico — Deus ou bufão - isto é o involuntário em mim, isso sou eu." ${ }^{45}$ No texto publicado, o "fanático" e o "profeta" são condensados no "fundador de religião", e "santo" ocupa o lugar de "Deus": Nietzsche também aprimora o "fanático" em "fundador de religião" e novamente coloca "santo" no lugar de "Deus". Nos textos especificamente preparados para publicação, a presunção desemboca em uma modéstia - a modéstia de uma presunção ainda mais forte. "Santo" é aquilo que é intocável e que vale como intocável. Aqueles que professam uma religião chamam de santo aquele que cria ou fortalece uma religião.

Nietzsche, que no Anticristo quer elucidar o valor do cristianismo e, com isso, superá-lo, devia temer, caso o conseguisse, que ele próprio acabasse sendo chamado de santo por aqueles que poderiam abdicar da velha crença em favor de uma nova ("Tenho um medo pavoroso de que um dia me declarem santo: perceberão porque publico este livro antes, ele deve evitar que se cometam abusos comigo"). O temor não foi descabido. O medo de Nietzsche procede: até o final do terceiro Reich, não foram poucos os novos "cultos de Nietzsche" que afloraram. ${ }^{46}$

${ }^{45}$ Fragmento póstumo de dezembro de 1888-início de janeiro de 1889, KSA 13, 25[6] 1.

${ }^{46}$ Cf. HOFFMANN, David M. Nietzsche-Kult. In: OTTMANN, Henning (Hg.) Nietzsche-Handbuch. Leben, Werk, Wirkung. Stuttgart\Weimar: Metzler, 2000. p. 485s e a literatura que é indicada lá. Além disso, BARBERA, Sandro; D'LORIO, Paolo; ULBRICHT, Justus H. (Hg.). Friedrich Nietzsche. Rezeption und Kultus. Pisa, 2004; HERTL, Michael. Der Mythos Friedrich Nietzsche und seine Totenmasken. Optische Manifeste seines Kults und Bildzitate in der Kunst. Würzburg, 2007; HINTZ, Hans. Liebe, Leid und Größenwahn. Eine integrative Untersuchung zu Richard Wagner, Karl May und Friedrich Nietzsche. Würzburg, 2007. Heinrich Köselitz, no túmulo de Nietzsche, disse que seu nome era "santo". Segundo Alfred Kubin, Nietzsche foi "verdadeiramente - nosso Cristo". Elisabeth Förster-Nietzsche queria erguer um mausoléu para seu irmão na península Chasté em Sils-Maria, em forma de uma pirâmide egípcia (no que fracassou) e pensou o Arquivo Nietzsche, fundado por ela em Weimar, como um local de culto e peregrinação (o que conseguiu). Ao lado do Arquivo, foi erigida uma estrutura semelhante a um templo, na qual deveria ser postada uma estátua de Nietszche em tamanho natural (a falta de dinheiro e o fim do terceiro Reich não permitiram que se chegasse a isso). Stefan George, por sua vez, tomou em Nietzsche a medida para seu culto de um novo império da poesia, que deveria ser a medida para o estado (Cf. RASCHEL, Heinz. Das Nietszche-Bild im George Kreis. Ein Beitrag zur Geschichte der deutschen Mythologeme. Berlin/New York 1984 (Monographien und Texte zur Nietzsche-Forschung, vol. 12), ASCHHEIM, Steven E. Nietzsche und die Deutschen. Karriere eines Kults. Trad. Klaus Laermann. Stuttgart/Weimar 1996, p. 72-85 e KARLAUF, Thomas. Stefan George. Die Entdeckung des Charisma. Biographie. München 2007, p. 293-296) e seu discípulo Ernst Bertram (Nietzsche. Versuch einer Mythologie, Berlin 1918) queria explicitamente elevar Nietzsche acima dos tempos como herói trágico. Além disso, incontáveis "movimentos" meio morais, meio religiosos, referiram-se a Nietzsche, entre outros o vegetarianismo, o feminismo e o sionismo... Algo comparável a isso não ocorreu de fato até agora com nenhum outro filósofo. Cf. KRAUSE, Jürgen. "Märtyrer" und "Prophet". Studien zum Nietzsche-Kult in der bildenden Kunst der Jahrhundertwende. Berlin/New York, 1984. (Monographien und Texte zur Nietzsche-Forschng, vol. 14). 
[10] Em sua obra, Nietzsche frequentemente fala do medo, sobretudo do medo religioso. Mas apenas aqui ele fala do seu próprio medo. Ele confrontase com esse sentimento, sobrepondo o "bufão" ao "santo": "Eu não quero ser um santo, seria antes um bufão... Talvez eu seja um bufão..." Um bufão é malicioso, sem ser levado a sério. Sua malícia não machuca. A gente pode deleitar-se com ela. Nietzsche não diz que é um bufão, mas sim que "talvez" seja um bufão e que, caso haja a necessidade de atribuir-lhe um determinado papel, ele prefere ser um bufão a ser um santo. Ele coloca o leitor diante da alternativa de decidir e o previne contra uma crença apressada.

O santo e o bufão situam-se em margens opostas do pensamento. O santo está lá onde o pensamento se torna intocável e passa a ser crença. O bufão, onde ele passa a ser descrença, onde o pensamento perde toda a seriedade e torna-se implausível, despropositado. O santo constrange a um ou-ou: é preciso que se creia nele ou se tem que negar sua santidade. Contrariamente, diante do bufão, permanecemos livres; pode-se ora acreditar nele, ora rir dele. Do ponto de vista da seriedade do "destino", da "tarefa" que Nietzsche toma para si como seu destino, o que lhe importa aqui é essa liberdade.

[11] Apesar disso, Nietzsche, à maneira de um santo, fala da verdade. Porém, fala como um santo precavido contra todos os outros santos: "E apesar disso, ou melhor, não apesar disso - pois até o momento nada houve mais mendaz do que os santos — , a verdade fala em mim." Ele joga o seu jogo de que os crentes se mantenham longe dele e que ele deve se manter livre deles, acima de tudo. A tensão do texto - aquilo de mais patético na obra do filósofo - é então levada ao extremo, é testemunho da paixão, da excitação e da raiva de um grande profeta, que com isso coloca ainda em questão toda a objetividade.

Nietzsche agora escreve e fala sem fôlego: usando reticências (“..."), como se o tempo não fosse suficiente para se expressar; usando intercalações (parênteses), como se ele próprio se interrompesse; com separações sinalizadas por travessões ("—"), como se não houvesse espaço para associações consequentes. ${ }^{47}$ Aquilo que se expressa é alcançado a partir daquilo que visivelmente não está expresso. Involuntariamente e por sua própria responsabilidade, o próprio leitor completa as elipses e as associações omitidas. O leitor lê o texto e, sem querer, passa a assumi-lo como se fosse seu autor. ${ }^{48}$

${ }^{47}$ Cf. FIETZ, Rudolf. Medienphilosophie. Musik, Sprache und Schrift bei Friedrich Nietzsche. Würzburg 1992, p. 380-382

${ }^{48}$ Wolfgang Iser, em Der implizite Leser (1972) e em Der Akt des Lesens (1976), assentou sua teoria da recepção científico-literária sobre este ponto. Ele parte do ponto em que o leitor "se descobre" a si mesmo juntamente com o sentido do romance — e faz isso com "deleite estético" (Der implizite Leser, p. 9). Segundo Iser, no século XIX, o romance atribuiu cada vez menos uma função explícita ao leitor e, com isso, forçou-o a encontrá-la por si próprio ou, com Nietzsche, a criá-la. No século XX, torna-se 
[12] Que verdade pode falar a partir do crítico mais mordaz da verdade, que prefere ser um bufão a ser um santo? Certamente não a verdade metafísica, que precisa estar adequada a um ser fora dela - e com certeza também nenhuma que possa ser objeto de crença religiosa. Nietzsche fala da sua verdade, que ele criou ("minha verdade"). Ela deve ser a verdade daquelas verdades, ser o "descobrimento" daquilo que até então valia de "forma mentirosa" como verdade. Ele não a expressa por travessões ("- "), mas deixa que também ela seja deduzida pelo leitor, sob sua própria responsabilidade: a verdade como liberdade de decisão sobre a verdade ou a verdade como liberdade. ${ }^{49}$ Contudo, a liberdade da decisão sobre a verdade é "terrível", pois ela não se apoia em nada, podendo acarretar dificuldades extremas e ainda conduzir a decisões erradas e a uma desorientação total, que precisará ser enfrentada sem religião e sem crenças.

Segundo o evangelho de João, Cristo disse acerca de si: "Eu sou o caminho, a verdade e a vida" (João, 14:6). Nietzsche não disse "eu sou a verdade", mas sim "a verdade fala em mim": quando a verdade fala, ela também fala em diferenciações, e em cada diferenciação sempre está presente também o outro lado da diferença, a outra alternativa possível. $\mathrm{Na}$ verdade está o erro indesejado ou a mentira desejada. A "mendacidade" desejada ou indesejada de um santo - ou daquele de quem se acredita que seja santo, que pode inclusive ser um filósofo — reside na desqualificação da alternativa sempre possível. E, desse modo, a verdade significa a decidibilidade da verdade pela afirmação de uma verdade única, que simultaneamente exclui a possibilidade de que ela possa ser a mentira ou o erro: "pois até agora chamou-se à mentira verdade."

um método deixar o leitor se envolver "em ilusões e ficções autoproduzidas" e forçá-lo à reflexão explícita deste envolvimento (Der implizite Leser, S. 11). Nietzsche, que não tinha Iser em vista, aqui visivelmente abre caminho para uma mudança de época. Também em seus textos "o leitor implícito" personifica "a totalidade das pré-orientações (Vororientierungen) que um texto ficcional oferece aos seus possíveis leitores como condições de recepção." Segundo essa ideia, o texto é uma "fôrma de estrutura oca": "ponto de vista e horizonte resultam [...] a partir da estrutura perspectivista do texto, não mais sendo, contudo, apresentados no próprio texto," para isso, o leitor precisa encontrar uma perspectiva orientada (Der Akt des Lesens, S. 60-62) - Heinz Schlaffer, em Das entfesselte Wort. Nietzsches Stil und die Folgen. München 2007, p. 38, faz disso uma sedução fascista: "ele (o leitor) espera saudosamente pelo guia, que sabe apontar os sinais de maneira correta, pois foi ele quem os colocou." Schlaffer, igualmente teórico da literatura, atribui ao estilo de Nietzsche a responsabilidade pelo delírio da prosa alemã e, em consequência, também da história alemã: "uma tal energia do estilo e da fala aumenta a importância da literatura alemã no início da modernidade, mas também a confusão da inteligência alemã e a fatalidade da política alemã" (p. 12s). Quais deveriam ser as condições de uma inteligência e uma política que se deixam confundir de tal maneira por um estilo literário?

${ }^{49}$ Sobre os antecedentes históricos e os pressupostos sistemáticos dessa verdade como liberdade, cf. SIMON, Josef. Wahrheit als Freiheit. Zur Entwicklung der Wahrheitsfrage in der neueren Philosophie. Berlin/New York, 1978 
[13] O "descobrimento" da verdade aparentemente sem alternativa - do valor mais alto da metafísica, da moral e da religião ocidentais, que serve de fundamento a todos os valores restantes - como sendo nada mais que uma mentira é a "transvaloração de todos os valores". Ela não pode mais ser uma verdade no antigo sentido, mas apenas uma "fórmula". Ela é a "fórmula" nietzscheana "para um ato de suprema autognose da humanidade", pelo qual todos serão afetados na medida em que todos, nas necessidades de suas vidas, acreditam em valores nos quais possam se apoiar. Pelo fato de que todos precisam partilhar da crença na verdade, ela se tornou algo óbvio e evidente, e justamente por isso é difícil romper com ela. Quem possui a liberdade para tal deve, por sua vez, assim como Nietzsche, ter passado por necessidades severas da vida que tornem esse rompimento possível.

Em Ecce Homo, Nietzsche expõe as condições de sua liberdade ("Por que sou tão sábio", "Por que sou tão inteligente..."), para descobrir por que justamente ele deveria ser capaz de uma transvaloração de todos os valores (nesse aspecto, Ecce Homo não é uma autobiografia, mas uma genealogia do seu pensamento ${ }^{50}$ ).

\footnotetext{
${ }^{50}$ O próprio Nietzsche, com sua fórmula "E assim me conto minha vida." (ECCe Homo, Prólogo), seduz para que se leia EcCe Homo como autobiografia, quando não como "auto-hagiografia" (Cf. SOMMER, Andreas Urs. Friedrich Nietzsches Der Antichrist. Ein philosophisch-historischer Kommentar. Basel, 2000, p. 46). Todavia, com essa fórmula, Nietzsche cita Zaratustra ("Ninguém me conta nada de novo: assim, conto-me eu a mim mesmo." Assim falou Zaratustra III, Das velhas e novas tábuas, §1) que certamente não tem em mente nenhuma autobiografia. Já Richard Samuel, em Friedrich Nietzsche's "Ecce Homo": an autobiography?, in: SCHLUDERMANN, Brigitte; MAURER, Karl-Werner (Hg.) Deutung und Bedeutung. Studies in German and comparative literature presented zu Karl-Werner Maurer. The Hague: Paris, 1973, p. 210-227, colocou um ponto de interrogação e chegou à conclusão: "Ecce Homo é antes uma análise do si de Nietzsche e uma auto-interpretação de seu trabalho" (p. 222; também para Rodolphe Gasché, no texto Autobiography as Gestalt, p. 275, "autobiografia" aparece entre aspas). O próprio subtítulo de Ecce Homo, "Como alguém se torna o que é", o qual, para Samuel, ainda fala em favor de uma autobiografia, remete mais a uma genealogia que adivinha e explora do que a uma autobiografia descritiva. De fato, os escritos autobiográficos de Nietzsche insinuam mais do que contam, e o pouco que o filósofo conta (e que, no entanto, é agrupado por Samuel sobre um fundamento textual antiquado revisto por Montinari) ele estiliza e torna enigmático de maneira demonstrativa ("diria, em forma de enigma, que como meu pai já morri, e como minha mãe ainda vivo e envelheço.") ECCe Homo, Por que sou tão sábio, §1; a esse respeito, Cf. KRELL, David Farrell. Consultations with the Parternal Shadow: Gasché, Derrida, and Klossowski on ECCe Homo, in HARRISON, Thomas [ed.]. Nietzsche in Italy. Saratoga: CA, 1988, p. 229-242). Jacques Derrida, que antes de tudo também fala de "autobiografia", após observaç̃es mais precisas, passa por fim para "alografia e tanatografia" (DERRIDA, Jacques. Otobiographien - Die Lehre Nietzsches und die Politik des Eigennamens, in: DERRIDA, Jacques; KITTLER, Friedrich. Nietzsche - Politik des Eigennamens. Wie man abschafft, wovon man spricht, Berlin, 2000, p. 7-63, aqui p. 40). Logo em seguida a Derrida, Gary Shapiro, em Nietzschean narratives. Bloomington/Indianapolis, 1989, mantém a pergunta aberta com sua fórmula "um balanço narrativo de sua própria vida [...] requerendo atenção" (p. 142). ECCe Homo deve mostrar como a transvaloração de todos os valores se realizou, em um primeiro caso, no próprio Nietzsche (p. 148) — em favor disso fala o § 9 de "Por que sou tão inteligente". Segundo Sarah Kofman, em sua interpretação dos textos de ECCe Homo (Explosion I: De 1'"ECCe Homo" de Nietzsche. Paris, 1992 e Explosion II: Les enfants de Nietzsche. Paris, 1993), se aqui se trata de uma autobiografia
} 
[14] Desde o século XVIII, o conceito usual para se referir às pessoas que, por motivos desconhecidos, criam novos padrões para todos, é o de gênio ("que em mim se fez gênio e carne"). Nietzsche deu ênfase durante toda sua vida à palavra "gênio" — o termo está presente centenas de vezes, em sua obra - e, contudo, aparece simultaneamente de maneira mordaz na "crença no próprio gênio" (Aurora, §542) e na "superstição relativa ao gênio" (Humano, demasiado humano I, §164) como sendo a "superstição do nosso século" (Fragmento do outono de 1887, KSA 12, 9[170] p. 435). Ele despiu a fala do gênio de todo "ressaibo mitológico ou religioso" (Humano, demasiado humano I, §231) e tomou para si próprio o mito da originalidade.

Um gênio é meramente alguém que, por força de suas próprias necessidades, encontra mais ou menos casualmente novas possibilidades para outras pessoas (Cf. Humano, demasiado humano I, §231). Por fim, ele traz a metáfora da dinamite também para o conceito do gênio: "Os grandes homens, como as grandes épocas, são materiais explosivos em que se acha acumulada uma tremenda energia; seu pressuposto é sempre, histórica e fisiologicamente, que por um longo período se tenha juntado, poupado, reunido, preservado com vistas a eles — que por um longo período não tenha havido explosão." (Cf. Crepúsculo dos Ídolos, Incursões de um extemporâneo, §44). O gênio, por seu turno, é, pois, mais um destino do que mérito. Ele nem ao menos tem o poder de acionar as suas forças acumuladas. São muito mais as circunstâncias e o tempo que possibilitam sua ação. Do mesmo modo, a presunção com a qual Nietzsche fala de si próprio como um gênio afunda em modéstia.

[15] O que está nas mãos do gênio é apenas — tornar-se "decente": "Minha sina quer que eu seja o primeiro homem decente, que eu me veja em oposição à mendacidade de milênios..." Da mesma forma que em "destino", "plebe" e "medo", a utilização por Nietzsche do conceito "decente" realiza uma transvaloração assombrosa, que eu não tenho condições de abordar aqui. Ela converge novamente sobre ele próprio, naquilo que ele chama de "honestidade intelectual" e que não encontra dimensão semelhante em mais ninguém.

[16] A mera decência intelectual (ou probidade, ou honestidade) é o parâmetro moral do seu pensamento, com o qual ele se vê "em oposição à

então se trata de uma que subverteu o "'gênero' autobiográfico” de maneira radical, inclusive o si ('autos') da vida ('bios') e da escrita ('graphein') e a unidade dominada que eles abrigam (cf. p. 22 e p. 29s). Walter Kaufmann, em Nietzsche. Philosoph - Psychologe - Antichrist, 1950, concebe a "apologia de Nietzsche" comparável à apologia de Sócrates. Enrico Müller e Andreas Urs Sommer, na introdução para uma série de artigos sobre ECCe Homo in: Nietzscheforschung 12 (2005), p. 127-131, aqui p. 128 e 130, passam da autobiografia para o conceito de "genealogia de si" ou "autogenealogia", em referência ao texto do autor Nietzsches Kritik der Vernunft seines Lebens. Zur Deutung von Der Antichrist und Ecce homo, in: Nietzsche-Studien 21 (1992), p. 163-183, aqui, p. 168. 
mendacidade de milênios..." Nietzsche não possui nada além dessa oposição — sua oposição pessoal — contra o antagonismo moral entre verdade e mentira, que dominou o pensamento europeu durante milênios.

A medida temporal com a qual ele avalia filosoficamente a sucessão dos acontecimentos são os milênios: ele tem diante dos olhos, sobretudo, os dois milênios transcorridos desde a fundação da filosofia e do cristianismo, e também que a Europa precisasse "se propor metas por milênios"; isto estaria sob a "compulsão à grande política." (Além de Bem e Mal, §208). Esta é a medida temporal da sua transvaloração.

[17] Nietzsche não mais se expressa como se ele "se visse em oposição" contra os velhos valores e contra a ausência de outras alternativas. Duas frases adiante ele diz que é um oposto. "Oposto" não é aqui nenhuma oposição conceitual como verdade e mentira, mas antes uma oposição existencial justamente contra tais oposições conceituais tidas como naturais e evidentes. Entrementes, não se faz mais nenhum esforço para refutá-las, ${ }^{51}$ chega-se a isso simplesmente pelo antagonismo de, agora, se viver, sentir e pensar diferentemente. Nietzsche confronta as oposições metafísicas a partir daquilo que o culto milenar delas rejeitou mais resolutamente: as sensações. $\mathrm{E}$, dentre as sensações, ele ainda parte daquelas que são as mais dificilmente conceitualizáveis e que, por isso, são consideradas as mais inconsistentes e menos delineáveis: as sensações gustativas e olfativas: ele "sente cheira..." a mentira.

[18] Uma razão fundamentada sobre oposições metafísicas não pode ser refutada por meio dela própria. Ao invés disso, é preciso um faro para conceitos e para as necessidades vitais às quais esses conceitos respondem: "Meu gênio está nas narinas..." No uso de conceitos, Nietzsche creditou "felizes narinas" a Zaratustra e "narinas sutis" a si próprio ${ }^{52}$. As narinas são os órgãos olfativos dos cavalos - Nietzsche brinca com o mito platônico da alma como um carro conduzido por uma parelha de cavalos (Fedro, $246 a-b$ ),

\footnotetext{
${ }^{51}$ Segundo Nietzsche, em Humano, demasiado humano II, O andarilho e sua sombra, §211, não se deve, diante de outros, esforçar-se para refutar suas ideias, mas procurar "pôr o que se quer definitivamente eliminar respeitosamente no gelo, sempre de novo, considerando que as idéias são teimosas em viver." A esse respeito, cf. WOTLING, Patrick. La culture comme problème. La redetermination nietzschéenne du questionnement philosophique, in: Nietzsche-Studien 37 (2008), p. 1-50, aqui p. 2s.

${ }^{52}$ Assim falou Zaratustra, III, O regresso e IV, Entre as filhas do deserto; Além de bem e mal, §252 e ECCe Homo, Aurora, \$1. Por fim, ele anota para si (provavelmente como adendo para ECCe Homo): “Eu ainda arrisco insinuar um proprium de minha natureza [...] Eu tenho algo, que chamo de minha narina interna. $\mathrm{Em}$ cada contato $\mathrm{com}$ homens ela é a primeira que revela a mim o grau de asseio interno [ _ _ - ] - eu cheiro justamente as "almas belas" como particularmente impuras. Como alguém se reconhece, ou como alguém se engana, se ele preza ter contato consigo sem ambiguidade, — se alguém se suporta ou se <tem> necessidade de um "ideal"... o idealista me cheira mal..." (fragmento póstumo do outono de 1888, KSA13, 21[8], p. 581).
} 
segundo o qual a razão simultaneamente guia os cavalos, mas também é puxada por eles. ${ }^{53}$

[19] No último terço do aforismo, Nietzsche traz mais uma vez e com mais força expressões anteriores ("sina" transforma-se em "fatalidade"; "crise sobre a Terra" em "comoções" e "terremotos"; "colisão" em "guerra dos espíritos"; "dinamite" em "explodido pelos ares"). Ele formula a oposição que ele é na forma de um enigma: "Eu contradigo como nunca foi contradito, e sou contudo o oposto de um espírito negador."

Em uma oposição existencial, uma dupla negação não se torna simplesmente uma afirmação. Um "espírito negador" típico seria um "espírito do ressentimento" (Para a Genealogia da Moral, II, §11), e um "espírito afirmador" precisa, por isso, ser livre de ressentimentos. Nietzsche tem a coragem de atribuir-se a si próprio "estar livre do ressentimento", porque em grande medida o filósofo foi compelido para isso: o esforço de simplesmente sobreviver à sua longa "enfermidade" — que já é "uma forma de ressentimento" e que poderia tê-lo compelido a um ressentimento profundo contra sua vida e contra toda a vida em geral — o coagiu para o "esclarecimento sobre o ressentimento" (ECce Homo, Por que sou tão sábio, §6).

No entanto, é difícil diferenciar entre o dizer-não ao ressentimento e o dizer-não do ressentimento, e, assim, o "contradizer como nunca foi contradito" é um ser-diferente e um pensar-diferente daquilo que os ressentimentos em geral querem. Nietzsche denominou essa postura como um "fazer não", que não pode ser novamente reduzido a conceitos gerais ou oposições conceituais, mas que apenas pode ser mostrado. Nietzsche mostrou isso na figura de Zaratustra ${ }^{54}$.

${ }^{53}$ Pensadores, anota ele para si, deveriam aprender a domar cavalos: "Deve-se elaborar seus impulsos. [...] Como pensador, ainda se poderia domar cavalos bem. Ou comandar." (fragmento póstumo do início - inverno de 1881, KSA 9, 11[31], p. 453.) Em Aurora, §201, ele emprega esta imagem para a "cultura nobre", e em Além de bem e mal, §284, ele faz da cavalgada segura sobre cavalos um sinal da nobreza em geral.

${ }^{54}$ Cf. ECCe Homo, Assim falou Zaratustra, §6: "O problema psicológico no tipo Zaratustra consiste em como aquele que em grau inaudito diz Não, faz Não a tudo a que até então se disse Sim, pode no entanto ser o oposto de um espírito de negação." - A diferença entre "dizer-não" e "fazer-não", por sua vez, não é contraditória. Nietzsche também une os conceitos (Cf. ECce Homo, Assim falou Zaratustra, §6 e Ecce Homo, Além de bem e mal, §1; fragmentos póstumos de novembro de 1887março de 1888, KSA 13, 11[228], p. 89. e 11[327], p. 139, fragmento póstumo KSA 13, 14[15], p. 225). O "fazer-não" pode igualmente nascer do "dizer-sim", e vice-versa (cf. os mesmos fragmentos póstumos de novembro de 1887-março de 1888 mencionados anteriormente), e, para se poder alcançar o "fazernão", "a segurança nas medidas de valor, o manejo consciente de uma unidade de método, a coragem alerta, o estar só e responder por si", precisa-se de "um prazer em dizer Não e desmembrar, e uma certa curiosidade refletida, que sabe manusear a faca de modo seguro e delicado, ainda que o coração sangre" (Além de bem e mal, §210). Sobre a inversão do "contra" que se opõe — o dizer-Não — para o dizer-Sim dionisíaco, que encerra as contradições em si, cf. SCHANK, Gerd. Dionysos gegen Gekreuzigten. Eine philologische und philosophische Studie zu Nietzsches "Ecce Homo". Bern u.a., 1993. p. 119 . 
[20] Mas o "oposto de um espírito negador" foi como Nietzsche reconheceu, n'O Anticristo, o "mensageiro alegre" — Cristo —, de quem ele falou como o "tipo Jesus": da mesma forma, ele também foi identificado como "a liberdade, a superioridade sobre todo sentimento de ressentimento" (O Anticristo, 40), sua "prática evangélica" (O Anticristo, §33) seria, no entanto, dogmatizada por uma recente "ironia histórico-universal" (O Anticristo, §36) em uma verdadeira religião do ressentimento (O Anticristo, 43). Nietzsche responde a isso com um novo "quinto evangelho", que ele chamou de Assim falou Zaratustra", ${ }^{55}$ e, por fim, fala ainda de si próprio: "Eu sou um mensageiro alegre, como nunca houve", um mensageiro alegre que quer novamente libertar a boa nova do pensamento ressentido que se depôs sobre ela, durante milênios. Isso pode inicialmente somente significar "tarefas" e "esperanças", mas também "comoções" e, como Nietzsche complementa no aforismo seguinte, igualmente "destruições". ${ }^{56}$ A afirmação existencial de uma orientação radicalmente nova torna necessária a dissolução da antiga.

[21] Para isso, Nietzsche precisa ser também o "homem da fatalidade." Anteriormente, ele ainda imputou à figura do Zaratustra ser o "portador do mais pesado destino, de uma fatalidade de tarefa." Ele, que "tem a mais dura e terrível percepção da realidade, que pensou o "mais abismal pensamento," o pensamento do eterno retorno do mesmo, "não encontra nisso, entretanto, objeção alguma ao existir, sequer ao seu eterno retorno - antes uma razão a mais para ser ele mesmo o eterno Sim a todas as coisas, "o imenso ilimitado Sim e Amém"..." (EcCe Homo, Assim falou Zaratustra, §6).

[22] Por fim, Nietzsche volta-se para a "crise", com a qual ele iniciou. Com a intensificação da dinamite (deliberadamente acionada) para causar o (inevitável) terremoto, ele mesmo detona a metáfora explosiva:57 "quando

${ }_{55}$ Carta de Nietzsche a Ernst Schmeitzner, de 13 de fevereiro de 1883, KSB 6, Nr. 375, p. 327. Cf. BLONDEL, Eric. Nietzsche: le "cinquième 'Évangile'"? Paris, 1980

${ }^{56}$ Cf. ECce Homo, Por que sou um destino, §2: “Eu sou, no mínimo, o homem mais terrível que até agora existiu; o que não impede que eu venha a ser o mais benéfico. Eu conheço o prazer de destruir em um grau conforme à minha força para destruir — em ambos obedeço à minha natureza dionisíaca, que não sabe separar o dizer Sim do fazer Não. Eu sou o primeiro imoralista: e com isso sou o destruidor par excellence."

${ }^{57}$ Heinrich Köselitz encorajou-o para isso O título "Ociosidade de um psicólogo", cuja possibilidade Nietzsche considerou em primeiro lugar para o "Crepúsculo dos Ídolos", pareceu a Köselitz "despretensioso demais". Ele exigiu "um título mais robusto e brilhante" — com a seguinte justificativa: "O senhor levou sua artilharia até as montanhas mais altas; tem canhões como nunca houve antes e precisa apenas atirar às cegas para colocar em pânico os arredores. Um passo gigantesco desses, pelo qual as montanhas estremecem nos fundamentos, não é mais nenhuma ociosidade" (Carta de Heinrich Köselitz a Nietzsche, 20 de setembro de 1888, KGB III/6, Nr. 581, p. 309). David S. Thatcher, em A Diagnosis of Idols. Percussions and Repercussions of a Distant Hammer, in: Nietzsche-Studien 14 (1985), p. 250-268, aqui, p. 252-257, apontou como Nietzsche expandiu essa metáfora em outras cartas 
a verdade sair em luta contra a mentira de milênios, teremos comoções, um espasmo de terremotos, um descolamento de montes e vales como jamais foi sonhado." Por último, ele inclui ainda as fórmulas "como nunca foi contradito", "como jamais houve", "como jamais foi sonhado."

O evento da "transvaloração de todos os valores" irá ultrapassar tudo aquilo que existiu, a luta e o espasmo na filosofia, ciência, moral e religião irão ultrapassar seus âmbitos e sacudir radicalmente os fundamentos da orientação corriqueira. A moral greco-cristã dogmatizada irá, em sua crise, mostrar o seu profundo enraizamento no pensamento dos europeus e, dessa maneira, também determinar a política, cujo instrumento mais extremo é a guerra. Guerras em torno de valores não serão mais meras lutas pelo poder, que poderão ser facilmente encerradas por dinastias ou por nações, da mesma forma que foram instigadas, mas sim "guerra[s] dos espíritos", com e por verdades, morais, religiões ou, dito simplesmente: ideologias ${ }^{59}$ que se espalham sorrateiramente e que, de repente, mostram consequências explosivas. Elas são, como o século XX suficientemente evidenciou, a dinamite mais perigosa, da qual o terrorismo no século XXI continua fazendo uso, literalmente. ${ }^{60}$

${ }^{58}$ Cf. fragmento póstumo de dezembro de 1888-início de janeiro de 1889, KSA 13, 25[6]1, p.639 Cf. também o rascunho da carta ao imperador Wilhelm II, do início de dezembro de 1888, KSB 8, Nr. 1171, p. 503s, que concorda em grande parte com o texto das notas.

${ }^{59}$ Cf. A Gaia Ciência, §283: Nietzsche espera uma "época que levará heroísmo para o conhecimento e travará guerras em nome dos pensamentos e das consequências deles", para o quê são necessários "homens mais ameaçados, mais fecundos e felizes", em resumo: espíritos livres no sentido nietzscheano, que vivam segundo o imperativo: "vivam em guerra com seus pares e consigo mesmos!" De modo semelhante, também Zaratustra diz: "se não podeis ser santos do conhecimento, sede, ao menos, seus guerreiros" (Assim falou Zaratustra, I, da guerra e dos guerreiros). Cf. KOFMAN, Sarah. Explosions II. p. 346s. - Nietzsche já havia utilizado a palavra "ideologia" antes, mas raramente. Cf. Além de bem e mal, §44 e fragmento póstumo de 1888, KSA 13, 15[113], p. 471.

${ }^{60}$ Nietzsche não toma partido - como suas anotações da época de Ecce Homo deixam claro — por povos ou nações, estamentos ou classes e menos ainda por raças, mas quer antes "criar um partido da vida, forte o suficiente para a grande política" (fragmento póstumo de dezembro de 1888-início de janeiro de 1889, KSA 13, 25[1], p. 637). Que, ao contrário, nas guerras entre dinastias ou nações, "se coloque diante dos canhões uma tal seleção de vigor e juventude e poder é loucura" (idem, 25[15], p. 645.) Nietzsche escreve ao jornalista parisiense Jean Bourdeau, para quem enviou sua "proclamação" contra a dinastia Hohenzollern: "Eu considero como honestamente possível colocar em ordem todo o absurdo da situação da Europa por meio de um tipo de gargalhada histórico-universal, sem precisar derrramar nem mesmo uma gota de sangue. Dito de outra forma: o Journal dos Débats é o bastante..." (carta de Nietzsche a Jean Bourdeau, possivelmente de 1 de janeiro de 1889, KSB 8, Nr. 1232, p. 570.) — Friedrich Balke, em Die Figuren des Verbrechers in Nietzsches Biopolitik, in: Nietzsche-Studien 32 (2003), p. 171-205, aqui, p. 198-205, persegue os discursos nietzscheanos de guerra e de guerra espiritual nas suas últimas anotações, as quais causaram ao próprio Giorgio Colli um temor tal que ele acreditou — sem base nos próprios textos, entretanto — na irrupção da loucura já aqui nestes textos. Segundo Balke, Nietzsche somente extrai as consequências daquilo que Michel Foucault chamou de "biopolítica", para a qual então Peter Sloterdijk chama a atenção, em Regras para o parque humano, uma biopolítica que desde sempre foi imanente à filosofia europeia: guerras seriam agora "feitas não mais em nome de um soberano, para defendê-lo, mas sim em nome da existência de todos." (Nota do tradutor: versões em português. SLOTERDIJK, Peter. Regras para o parque humano. Uma resposta à 
Nietzsche utilizou a expressão "grande política" bem cedo e primeiramente de maneira irônica, referindo-se ao novo Reich alemão. ${ }^{61} \mathrm{Em}$ sua obra tardia, o filósofo denomina "grande" não aquilo que predomina sobre outros, mas aquilo que não é negado por sua contradição, que não é destruído por ela, que, por meio dela, torna-se ainda mais fecundo, que pode crescer com a ajuda dela. Assim, a "grande razão do corpo" faz da "pequena razão" - da "razão pura" — seu instrumento e brinquedo (Assim falou Zaratustra, I, Dos desprezadores do corpo); uma "grande saúde" pode se "abandonar" a doenças graves e, com isso, tornar-se ainda mais robusta ( $A$ Gaia Ciência, §382); "a grande vida" vive-se a partir da guerra (Crepúsculo dos Ídolos, Moral como antinatureza, §3); a "grande tolerância" pode tolerar a intolerância com "magnânimo autocontrole" e ainda crescer nela ( $O$ Anticristo, §38) e o "grande estilo" pode unir o pathos mais elevado com sobriedade e jovialidade (ECCe Homo, Por que escrevo livros tão bons, §4). Nesse sentido, "grande política" é a política que encerra em si aquilo que comumente lhe é contrário, espírito na forma de moral, religião, ciência, filosofia ou simplesmente "guerra dos espíritos". Ainda nas suas anotações temerárias sobre a "grande política", que o filósofo rascunhou na virada para o ano de 1889, interessa a ele abordar uma política de guerras "não entre povo e povo" e "não entre classes", porém, contra "todos os absurdos acasos de povo, estado, raça, profissão, educação, formação: uma guerra como entre ascensão e declínio, entre vontade de vida e desejo de vingança contra a vida, entre honestidade e mentiras traiçoeiras..." 62

carta de Heidegger sobre o humanismo. Trad. José Oscar de Almeida Marques. São Paulo: Estação Liberdade, 2000 e FOUCAULT, Michel. História da Sexualidade I: A Vontade de Saber. Trad. Maria Thereza da Costa Albuquerque e José Augusto Guilhon Albuquerque. Rio de Janeiro: Graal, 1993.)

${ }^{61}$ Henning Ottman, em Philosophie und Politik bei Nietzsche, p. 232-292, apresentou o sentido da "grande política" em Nietzsche, envolvendo todas as suas facetas.

${ }^{62}$ Fragmento póstumo de dezembro de 1888-início de janeiro de 1889, KSA 13, 25[1], p. 637. — Aqui, Nietzsche também anotou - depois da experiência do século XX — suas frases mais pavorosas: A grande política "quer criar um poder forte o suficiente para cultivar a humanidade como um todo e como algo superior, com impiedosa dureza contra a degenerescência e o parasitário na vida, — contra aquilo que corrompe, envenena, calunia, faz perecer... e vê na destruição da vida o desenho de um tipo superior de almas." Contudo, este também não é nenhum programa para o assassinato de deficientes e, antes de tudo, seguramente não visa ao genocídio dos judeus da Europa. Foram antes de tudo os nazistas, que com seu nacionalismo, socialismo e antissemitismo, seriam um horror para Nietzsche e para os quais os escritos do filósofo eram "antinacionalistas demais, antialemães demais, antifilisteístas demais, antirevanchistas demais, anticoletivistas demais, antimilitaristas demais, antiantirracionalistas demais, anti-antissemitistas demais, [...] insuportáveis demais para qualquer política de ressentimento" (SLOTERDIJK, Peter. Über die Verbesserung der guten Nachricht, p. 59.). Uma vez que os nazistas jamais teriam podido apelar para ele sem falsificações, eles mudaram os conceitos de degenerescência e de parasitário deste modo. E Nietzsche também não publicou essas anotações que ele escreveu na mesma época do rascunho do primeiro aforismo de "Por que sou um destino". Nas anotações para EcCe Homo, Por que sou um destino, §1, segue ainda um parágrafo, que ele igualmente não publicou: "Nada conheço que se contrapusesse mais ao sentido supremo de minha tarefa do que o incitamento, digno de maldição, ao egoísmo de povos e raças que agora tem pretensão ao <nome> de 'grande política'; não tenho palavras para exprimir meu desprezo pelo nível 


\section{A decidibilidade da verdade como destino da humanidade}

Façamos um resumo: o aforismo tira as conclusões do "descobrimento" nietzscheano da moral cristã, a qual se articula com os mecanismos da filosofia grega e impregnou a Europa, durante milênios. Sua revelação, seu esclarecimento, tornou-se possível por meio da inquietação da consciência que ela própria cultivou. Na época de Nietzsche, o valor de uma verdade absoluta dissociada da vida e dos seus destinos - a qual deveria dar sentido a todos os sofrimentos da vida e ser adequadamente reconhecida ${ }^{63}$ — tornouse visivelmente implausível.

Uma vez que, na tradição europeia, todos os valores restantes se apoiavam neste valor, deveria então surgir nesse momento uma inevitável "transvaloração de todos os valores". Segundo Nietzsche, sua "sorte" e "fatalidade" foi ver isso com olhar claro e manifestar-se sobre isso com integridade incorruptível, e, por conta disso, tornar-se o destino da humanidade europeia; e, visto que o mundo em geral está sob a influência europeia, também no destino da humanidade como um todo.

O "fenômeno" da transvaloração responde, segundo Nietzsche, a eventos histórico-universais transcorridos em milênios: à pressão socrática por uma verdade impessoal em nome do deus délfico Apolo, para a qual o ateniense, contudo, não fez valer nenhum exemplo; e ao testemunho de Jesus de uma verdade do amor, para a qual ele próprio era o único exemplo. Com suas personalidades, ambos deram autoridade a uma verdade - a qual os ultrapassou - e, com suas mortes, assumiram a responsabilidade por ela. ${ }^{64}$

<espiritual> que agora - na figura do chanceler alemão e com atitudes de oficial pruss <iano $>$ da casa Hohenzollern — se acredita chamado para diretor da história da humanidade [...] há mais dinamite entre o céu e a Terra do que se permitem sonhar esses idiotas purpureados..." (fragmento póstumo de dezembro de 1888-início de janeiro de 1889, KSA 13, 25[6], p. 640s). — Sobre o §36 de Crepúsculo dos Ídolos, incursões de um extemporâneo, bastante evocado por médicos nazistas e outras "passagens" mal-afamadas, cf. a nota final do texto do autor, Eugenik und die Zukunft im außermoralischen Sinn: Nietzsches furchtlose Perspektiven, in: SORGNER, Stefan Lorenz; BIRX, H. James; KNOEPFLLER, Nikolaus (Hg.). Eugenik und die Zukunft. Freiburg/München, 2006, p. 27-42, aqui, p. 38-41.

${ }^{63}$ Cf. Fragmento póstumo de junho de 1887, KSA 12, 5[71] 1. p. 215 (fragmento Lenzer-Heide "O niilismo europeu")

${ }^{64} \mathrm{O}$ título de Nietzsche ECCe Homo, que aparece três vezes em sua obra (veja abaixo), poderia também lembrar a tradicional cerimônia do "Ecce" na escola de Pforta, que impressionava profundamente seus participantes: a celebração dos mortos para professores e alunos falecidos e pelo término do ano litúrgico, no sábado antes do domingo dos mortos (Totensonntag). Alunos e professores cantavam um

"Ecce quomodo moritur justus". Segundo múltiplos relatos, a cerimônia se fixou de tal forma na memória dos alunos de Pforta, que, quando eles pensavam na sua morte, espontaneamente ligavam a ela o "Ecce". Mesmo os nazistas, quando, em 1935, transformaram Pforta em um "estabelecimento de ensino político-nacional", conservaram a cerimônia do "Ecce". Cf. BOHLEY, Reiner. Die Christlichkeit einer Schule: Schulpforte zur Schulzeit Nietzsches, org. e posfácio de Kai Agthe (Reihe manuskript. Archiv zur Bildungs- und Wissenschaftsgeschichte, vol. 4), Jena/Quedlinburg 2007, p. 135-138. Nietzsche esteve presente a cinco "Ecces" comuns e sete extraordinários e, em geral, 
A ambos seguiram-se outros, que tomaram a verdade deles como algo supraindividual, geral, como a verdade em geral. Paulo sustentou a verdade cristã do amor, para que ela pudesse se espalhar pelo mundo, através da verdade grega geral. Seus sucessores preservaram a verdade grega em nome da cristã e, dessa maneira, embora as origens sejam bastante distintas, ambas as verdades encontraram apoio uma na outra, durante milênios.

Quando o valor absoluto dessa verdade greco-cristã se tornou implausível, as "tarefas" de dar novos valores à humanidade e as "esperanças" que repousam sobre elas recaem novamente sobre aqueles que possuem a força para isso. Uma força que deve vir do mesmo modo como a força de Sócrates e de Jesus de Nazaré, ou ao menos ser considerada como igual.

Nietzsche tentou dar forma a essa força, no Zaratustra, novamente a figura de uma única pessoa com uma comprovada "coragem para permanecer só" e para a "solidão" também no pensar. Ele posicionou seu filosofar sob o "conceito de Dioniso", do deus que reúne em si todas as contradições sobre as quais os homens dispõem o seu mundo, e põe-nas sempre de novo em movimento contra a necessidade de consolidá-las e de conseguir, com isso, um apoio duradouro.

Desse modo, os homens que se mantêm ligados à verdade de uma generalidade atemporal, que agora se tornou igualmente "mentira", devem novamente se tornar livres: tanto para a vida, onde tudo tem seu tempo, inclusive a verdade; como para a nova verdade de uma decisão sobre a verdade de tempos em tempos. Assim, a verdade também se tornará objeto da política, "grande política" de espíritos que possuem a força para decisões sobre a verdade. E dessa forma, mesmo esse aforismo inaudito pode também ser levado filosoficamente a sério.

menciona-os nas cartas (cf. entre outras, carta de Nietzsche a Franziska Nietzsche, 20 de agosto de 1860, KSB 1, Nr. 169, p. 120). Com ECce Homo, ele também cantou para si (com ironia renovada?) sua própria canção de morte. Assim, ele ainda acrescenta um poema "Ecce homo", inspirado em Goethe, no "prelúdio em rimas alemãs", "brincadeira, astúcia e vingança", transferido para A Gaia Ciência: "Sim, eu sei de onde sou! / Insaciável como o fogo / Eu ardo e me consumo. / Tudo o que toco vira flama / E tudo o que deixo, carvão: / Sou fogo, não há dúvida." (Nr. 62.). Mas ele sabe que também "algum pobre e vadio moralista" pode ele próprio se desenhar "no muro" e dizer "ecce homo!" para isso (Crepúsculo dos Ídolos, moral como antinatureza, 6) e por fim ele intitulou a genealogia de seu "destino" com Ecce Homo (o que leva Daniel Conway, em Nietzsche's Doppelgänger, p. 63-66, à acusação de "duplicidade" e de "ressentimento"). 
STEGMAIER, Werner. Nietzsche como destino da filosofia e da humanidade? Interpretação contextual do $\S 1$ do capítulo "Por que sou um destino", de Ecce Homo. Traducão João Paulo Simões Vilas Bôas. Trans/Form/Ação, (Marília); v.34, n.1, p. 173-206, 2011.

ABSTRACT: The following translation is a reduced and revised version of the paper Schicksal Nietzsche? Zu Nietzsches Selbsteinschätzung als Schicksal der Philosophie und der Menschheit (Ecce Homo, Warum ich ein Schicksal bin \$1)" - originally published in Nietzsche-Studien 37 (2008) which was specially prepared to be presented in lecture organized by the Grupo de Pesquisa Spinoza \& Nietzsche (Spinoza \& Nietzsche research group - SpiN), in the Universidade Federal do Rio de Janeiro (Rio de Janeiro's Federal University), on September 14, 2009. In the text, the autor employs his own philological-hermeneutical methodology, which is called contextual interpretation, in the purpose to clarify the concepts of the first aphorism from "Why I am a destiny", from EcCe Homo, in its own context, in the context of ECCe Homo and in the context of the entire work from Nietzsche.

KEYWORDS: ECCe Homo. Contextual interpretation. Destiny. Madness. Truth.

\section{Referências}

ASCHHEIM, Steven E. Nietzsche und die Deutschen. Karriere eines Kults. Trad. Klaus Laermann. Stuttgart: Metzler, 1996.

BALKE, Friedrich. Die Figuren des Verbrechers in Nietzsches Biopolitik. In: ABEL, Günther; SIMON, Josef; STEGMAIER, Werner (Org.). Nietzsche-Studien. Berlim: Walter de Gruyter, 2003. v. 32, p. 171-205.

BOHLEY, Reiner. Die Christlichkeit einer Schule: Schulpforte zur Schulzeit Nietzsches. In: AGTHE, Kai (Org.). Reihe manuskript. Jena: Quedlinburg 2007. p. 135-138. (Archiv zur Bildungs- und Wissenschaftsgeschichte, v. 4).

CONWAY, Daniel. Nietzsche's Doppelgänger: Affirmation and Resentment in Ecce Homo. In: ANSELL-PEARSON, Keith; CAYGILL, Howard. (Org.). The fate of the new Nietzsche. London: Aldershot, 1993. p. 55-78.

DERRIDA, Jacques. Otobiographien - Die Lehre Nietzsches und die Politik des Eigennamens. In: DERRIDA, Jacques; KITTLER, Friedrich. Nietzsche - Politik des Eigennamens. Wie man abschafft, wovon man spricht. Berlim: Walter de Gruyter, 2000. p. 7-63.

FOUCAULT, Michel. História da sexualidade I: a vontade de saber. Tradução Maria Thereza da Costa Albuquerque e José Augusto Guilhon Albuquerque. Rio de Janeiro: Graal, 1993.

HABERMAS, Jürgen. O discurso filosófico da modernidade. São Paulo: Martins Fontes, 2000.

HEIDEGGER, M. Nietzsche. Tradução Marco Antonio Casanova. Rio de Janeiro: Forense Universitária, 2007. v. 1. 
HOFFMANN, David M. Nietzsche-Kult. In: OTTMANN, Henning (Org.) Nietzsche-Handbuch. Leben, Werk, Wirkung. Stuttgart: Metzler, 2000. p. 485s.

HOWEY, Richard Lowell. Some reflections on irony in Nietzsche. In: ABEL, Günther; SIMON, Josef; STEGMAIER, Werner (Org.). Nietzsche-Studien. Berlim: Walter de Gruyter, 1975. v. 4, p. 36-51.

JASPERS, Karl. Nietzsche. Einführung in das Verständnis seines Philosophierens. Berlim: Walter de Gruyter, 1936.

KORNBERBER, Martin. Zur Genealogie des "Ecce Homo". In: ABEL, Günther; SIMON, Josef; STEGMAIER, Werner (Org.).Nietzsche-Studien. Berlim: Walter de Gruyter, 1998. v. 27, p. 319-338.

KRAUSE, Jürgen. "Märtyrer" und "Prophet". Studien zum Nietzsche-Kult in der bildenden Kunst der Jahrhundertwende. Berlim: Walter de Gruyter, 1984. (Monographien und Texte zur Nietzsche-Forschng, v. 14).

KRELL, David Farrell. Consultations with the Parternal Shadow: Gasché, Derrida, and Klossowski on Ecce Homo. In: HARRISON, Thomas (Org.). Nietzsche in Italy. Saratoga: CA, 1988. p. 229-242.

KRUMMEL, Richard Frank. Nietzsche und der deutsche Geist: Ausbreitung und Wirkung des Nietzscheschen Werkes im deutschen Sprachraum bis zum Todesjahr. Ein Schrifttumsverzeichnis der Jahre 1867-1900. Berlim: Walter de Gruyter, 1998. (Monographien und Texte zur Nietzsche-Forschung, v. 3).

LEMM, Vanessa. Animality, creativity and historicity: a reading of Friedrich Nietzsche's Vom Nutzen und Nachtheil der Historie für das Leben. In: ABEL, Günther; SIMON, Josef; STEGMAIER, Werner (Org.). Nietzsche-Studien. Berlim: Walter de Gruyter, 2007. v. 36, p. 169-200.

MIRABILE, Paul. The nomadic thought. Friedrich Nietzsche und Zhuang Zi. Convergences and Divergences. In: ABEL, Günther; SIMON, Josef; STEGMAIER, Werner (Org.). Nietzsche-Studien. Berlim: Walter de Gruyter, 2004. v. 33, p. 237-277.

MONTINARI, Mazzino. Ein neuer Abschnitt in Nietzsches "Ecce Homo". In: ABEL, Günther; SIMON, Josef; STEGMAIER, Werner (Org.). Nietzsche-Studien. Berlim: Walter de Gruyter, 1972. v. 1, p. 380-418.

MÜLLER, Enrico. Die Griechen im Denken Nietzsches. Berlim: Walter de Gruyter, 2005. (Monographien und Texte zur Nietzsche-Forschung, v. 50).

NEHAMAS, Alexander. Nietzsche: Life as Literature. London: Harvard University Press, 1985.

NIETZSCHE, Friedrich. Werke: Kritische Gesamtausgabe. Org. Giorgio Colli e Mazzino Montinari. Berlim: Walter de Gruyter, 1985-2010. (9 tomos).

OTTMANN, Henning. Anti-Lukács. Eine Kritik der Nietzsche-Kritik von Georg Kukács. In: ABEL, Günther; SIMON, Josef; STEGMAIER, Werner (Org.). NietzscheStudien. Berlim: Walter de Gruyter, 1984. v. 13, p. 570-586. 
OTTMANN, Henning. Philosophie und Politik bei Nietzsche. Berlim: Walter de Gruyter, 1999. (Monographien und Texte zur Nietzsche-Forschung, v. 17).

RASCHEL, Heinz. Das Nietszche-Bild im George Kreis. Ein Beitrag zur Geschichte der deutschen Mythologeme. Berlim: Walter de Gruyter, 1984. (Monographien und Texte zur Nietzsche-Forschung, v. 12).

SAMUEL, Richard. Friedrich Nietzsche's "Ecce Homo": an autobiography? In: SCHLUDERMANN, Brigitte; MAURER, Karl-Werner (Org.). Deutung und Bedeutung. Studies in German and comparative literature presented zu KarlWerner Maurer. The Hague: Paris, 1973. p. 210-227.

SEDGWICK, Peter. Nietzsche, normativity and will to power. In: ABEL, Günther; SIMON, Josef; STEGMAIER, Werner (Org.). Nietzsche-Studien. Berlim: Walter de Gruyter, 2007. v. 36, p. 201-229.

SHAPIRO, Gary. Nietzschean narratives. Bloomington: Indianapolis, 1989.

SIMON, Josef. Wahrheit als Freiheit. Zur Entwicklung der Wahrheitsfrage in der neueren Philosophie. Berlim: Walter de Gruyter, 1978.

SLOTERDIJK, Peter. Regras para o parque humano. Uma resposta à carta de Heidegger sobre o humanismo. Tradução José Oscar de Almeida Marques. São Paulo: Estação Liberdade, 2000

SLOTERDIJK, Peter. Über die Verbesserung der guten Nachricht. Nietzsches fünftes "Evangelium". Discurso proferido em 25 de agosto de 2000, em Weimar, por ocasião dos 100 anos de morte de Friedrich Nietzsche, Frankfurt am Main, 2001.

STEGMAIER, Werner. 'Philosophischer Idealismus' und die 'Musik des Lebens'. Zu Nietzsches Umbang mit Paradoxien. Eine kontextuelle Interpretation des Aphorismus Nr.372 der Fröhlichen Wissenschaft. In: ABEL, Günther; SIMON, Josef; STEGMAIER, Werner (Org.). Nietzsche-Studien. Berlim: Walter de Gruyter, 2004. v. 33, p. 90-128.

STEGMAIER, Werner. Auseinandersetzung mit Nietzsche I - Metaphysische Interpretation eines Anti-Metaphysikers. In: THOMÄ, Dieter (Org.). HeideggerHandbuch. Leben - Werk - Wirkung. Stuttgart: Metzler, 2003. p. 202-210.

STEGMAIER, Werner. Nach Montinari. Zur Nietzsche-Philologie. In: ABEL, Günther; SIMON, Josef; STEGMAIER, Werner (Org.). Nietzsche-Studien. Berlim: Walter de Gruyter, 2007. v. 36, p. 80-94.

STEGMAIER, Werner. Nietzsches Neubestimmung der Wahrheit. In: ABEL, Günther; SIMON, Josef; STEGMAIER, Werner (Org.). Nietzsche-Studien. Berlim: Walter de Gruyter, 1985. v. 14, p. 69-95.

STEGMAIER, Werner. Philosophie der Orientierung. Berlim: Walter de Gruyter, 2008.

STEGMAIER, Werner. Schicksal Nietzsche? Zu Nietzsches Selbsteinschätzung als Schicksal der Philosophie und der Menschheit (Ecce Homo, Warum ich ein Schicksal bin 1). In: ABEL, Günther; SIMON, Josef; STEGMAIER, Werner (Org.).NietzscheStudien. Berlim: Walter de Gruyter, 2008. v. 37, p. 62-114. 
STEINBUCH, Thomas. A commentary on Nietzsche's Ecce Homo. Londres: Lanham, 1994.

THATCHER, David S. A Diagnosis of Idols. Percussions and Repercussions of a Distant Hammer. In: ABEL, Günther; SIMON, Josef; STEGMAIER, Werner (Org.). Nietzsche-Studien. Berlim: Walter de Gruyter, 1985. v. 14, p. 250-268.

WOTLING, Patrick. La culture comme problème. La redetermination nietzschéenne du questionnement philosophique. In: ABEL, Günther; SIMON, Josef; STEGMAIER, Werner (Org.). Nietzsche-Studien. Berlim: Walter de Gruyter, 2008. v. 37, p. 1-50. 